\title{
Chronostratigraphic framework and provenance of the Ossa-Morena Zone Carboniferous basins (southwest Iberia)
}

\author{
Manuel Francisco Pereira ${ }^{1}$, Cristina Gama ${ }^{1}$, Ícaro Dias da Silva ${ }^{2}$, José Brandão Silva ${ }^{3}$, Mandy Hofmann ${ }^{4}$, \\ Ulf Linnemann ${ }^{4}$, and Andreas Gärtner ${ }^{4}$ \\ ${ }^{1}$ Instituto de Ciências da Terra, Departamento de Geociências, ECT, Universidade de Évora, \\ Apt. 94, Évora, 7002-554, Portugal \\ ${ }^{2}$ Instituto Dom Luiz, Faculdade de Ciências da Universidade de Lisboa, Campo Grande, Lisbon, 1749-016, Portugal \\ ${ }^{3}$ Instituto Dom Luiz, Departamento de Geologia, Faculdade de Ciências da Universidade de Lisboa, \\ Campo Grande, Lisbon, 1749-016, Portugal \\ ${ }^{4}$ Senckenberg Naturhistorische Sammlungen Dresden, Museum für Mineralogie und Geologie, Dresden, Germany
}

Correspondence: Manuel Francisco Pereira (mpereira@uevora.pt)

Received: 26 February 2020 - Discussion started: 11 March 2020

Revised: 19 May 2020 - Accepted: 26 May 2020 - Published: 9 July 2020

\begin{abstract}
Carboniferous siliciclastic and silicic magmatic rocks from the Santa Susana-São Cristovão and Cabrela regions contain valuable information regarding the timing of synorogenic processes in SW Iberia. In this region of the Ossa-Morena Zone (OMZ), late Carboniferous terrigenous strata (i.e., the Santa Susana Formation) unconformably overlie early Carboniferous marine siliciclastic deposits alternating with volcanic rocks (i.e., the Toca da Moura volcano-sedimentary complex). Lying below this intra-Carboniferous unconformity, the Toca da Moura volcano-sedimentary complex is intruded and overlain by the Baleizão porphyry. Original sensitive high-resolution ion microprobe (SHRIMP) and laser ablation inductively coupled plasma mass spectrometry (LA-ICP-MS) U-Pb zircon are presented in this paper, providing chronostratigraphic and provenance constraints since available geochronological information is scarce and only biostratigraphic ages are currently available for the Santa Susana-São Cristovão region. Our findings and the currently available detrital zircon ages from Paleozoic terranes of SW Iberia (Pulo do Lobo Zone - PLZ - South Portuguese Zone - SPZ - and OMZ) were jointly analyzed using the $\mathrm{K}-\mathrm{S}$ test and multidimensional scaling (MDS) diagrams to investigate provenance. The marine deposition is constrained to the age range of ca. 335$331 \mathrm{Ma}$ (Visean) by new U-Pb data for silicic tuffs from the
\end{abstract}

Toca da Moura and Cabrela volcano-sedimentary complexes. The Baleizão porphyry, intrusive in the Toca da Moura volcano-sedimentary complex, yielded a crystallization age of ca. $318 \mathrm{Ma}$ (Bashkirian), providing the minimum age for the overlying intra-Carboniferous unconformity. A comparison of detrital zircon populations from siliciclastic rocks of the Cabrela and Toca de Moura volcano-sedimentary complexes of the OMZ suggests that they are derived from distinct sources more closely associated with the SPZ and PLZ than the OMZ. Above the intra-Carboniferous unconformity, the Santa Susana Formation is the result of the recycling of distinct sources located either on the Laurussian side (SPZ and PLZ) or Gondwanan side (OMZ) of the Rheic suture zone. The best estimate of the crystallization age of a granite cobble which was found in a conglomerate from the Santa Susana Formation yielded ca. 303 Ma (KasimovianGzhelian), representing the maximum depositional age for the terrestrial strata. The intra-Carboniferous unconformity seems to represent a stratigraphic gap of approximately 12 $14 \mathrm{Myr}$, providing evidence of the rapid post-accretion and collision uplift of the Variscan orogenic belt in SW Iberia (i.e., the OMZ, PLZ, and SPZ). 


\section{Introduction}

The Variscan orogen that extends from central Europe to Iberia was reworked through discrete Carboniferous sedimentary cycles during the Laurussia-Gondwana convergence, giving rise to the formation of marine and terrestrial basins. In SW Iberia, stratigraphic correlation has been proposed for the Carboniferous synorogenic strata found in the three main tectonostratigraphic divisions of the Variscan orogen: the Ossa-Morena (OMZ), Pulo do Lobo (PLZ), and South Portuguese (SPZ) zones (Quesada and Oliveira, 2019, and references therein).

The Carboniferous siliciclastic strata in the Santa SusanaSão Cristovão and Cabrela regions (OMZ) include fossils indicating Carboniferous to Kasimovian biostratigraphic ages (Teixeira, 1938-1940, 1941; Lemos de Sousa and Wagner, 1983; Wagner and Lemos de Sousa, 1983; Pereira et al., 2006; Machado et al., 2012; Lopes et al., 2014). In the Santa Susana-São Cristovão region, late Carboniferous siliciclastic strata of the Santa Susana Formation unconformably overlie (i) the Baleizão volcanic-subvolcanic suite that was previously dated with whole-rock $\mathrm{Rb}-\mathrm{Sr}$ isochrones (Priem et al., 1986) and (ii) the early Carboniferous Toca da Moura volcano-sedimentary complex, which includes volcanic rocks that have never been dated. This intraCarboniferous unconformity was generated as a consequence of regional uplift and falling sea level, leading to a change in the depositional environment from early Carboniferous marine to late Carboniferous terrestrial (Gonçalves and Carvalhosa, 1984; Oliveira et al., 1991; Machado et al., 2012). The provenance of the abovementioned Carboniferous strata has been discussed based on petrographic, paleontological, and detrital zircon geochronology evidence (Pereira et al., 2006; Machado et al., 2012; Lopes et al., 2014; Dinis et al., 2018).

In this paper, sensitive high-resolution ion microprobe (SHRIMP) and laser ablation inductively coupled plasma mass spectrometry (LA-ICP-MS) U-Pb analyses were performed on zircon grains from silicic volcanic, subvolcanic, and siliciclastic rocks sampled in the Santa SusanaSão Cristovão and Cabrela regions (OMZ; SW Iberia). The aim of this geochronological study is to establish the chronostratigraphic framework of these Carboniferous strata and to discuss their provenance using a statistical approach (Kolmogorov-Smirnov test and multiscaling diagrams). Thus we pay tribute to José Ramón MartínezCatalán, who devoted part of his career to investigating the Carboniferous synorogenic basins of NW Iberia.

\section{Geological setting}

In SW Iberia, the tectonic limit between the OMZ (Gondwanan side) and the PLZ and SPZ (Laurussian side) has been regarded as constituting the tectonically reworked suture zone of the Rheic Ocean (Andrade, 1983; Quesada et al., 1994; Simancas et al., 2005; Díaz-Apiroz et al., 2006; Ribeiro et al., 2007; Pereira et al., 2017a) (Fig. 1). This Paleozoic suture zone has been defined along the Beja-Acebuches Ophiolitic Complex (Fonseca et al., 1999, and references therein). The Beja-Acebuches Ophiolitic Complex is separated from the Beja Igneous Complex (Jesus et al., 2007, 2016) by a strike-slip fault. Metabasalts and metagabbros (i.e., the Mombeja unit of Andrade, 1983) from the BejaAcebuches Ophiolitic Complex have been dated at ca. 340$332 \mathrm{Ma}$ (U-Pb zircon; Azor et al., 2008), while in the Beja Igneous Complex gabbro and granitic rocks are relatively older, yielding crystallization ages of ca. 353-342 Ma (U-Pb zircon; Jesus et al., 2007; Pin et al., 2008). Trace element and isotopic signatures of Beja Igneous Complex plutonic rocks indicate crustal contamination of parental magmas deriving from a depleted asthenospheric mantle reservoir (Santos et al., 1990; Pin et al., 2008; Jesus et al., 2016). The plutonic rocks of the Beja Igneous Complex show well-defined intrusive contacts with previously deformed and metamorphosed sedimentary and igneous rocks of the OMZ basement (Rosas et al., 2008; Pin et al., 2008). The Beja Igneous Complex also includes the São Cristovão-Alcáçovas subvolcanic complex (Gonçalves and Carvalhosa, 1984), composed of silicic subvolcanic and volcanic rocks (i.e., the Baleizão unit of Andrade, 1983), granophyres, and porphyries dated at ca. $319 \mathrm{Ma}$ (whole-rock Rb-Sr isochrones; Priem et al., 1986), associated with diabases. Porphyry dikes are found cutting across the OMZ basement that is here formed by Cambrian igneous rocks from ca. $527 \mathrm{Ma}$ (Alcáçovas gneiss; Chichorro et al., 2008) deformed and metamorphosed in the early Carboniferous at $340 \pm 6 \mathrm{Ma}$ (Pereira et al., 2009). The major and trace element geochemistry of the Baleizão porphyries indicates a calc-alkaline rhyolitic, rhyodacite, and andesitic composition typical of magmas produced at convergent plate boundaries (Santos et al., 1987; Caldeira et al., 2007; Ferreira et al., 2014). The Baleizão porphyries occur as dikes and sills (Andrade, 1927) (Fig. 3a, b), overlying (Gonçalves and Carvalhosa, 1984) the early Carboniferous siliciclastic and volcanic rocks of the Toca da Moura volcano-sedimentary complex (Santos et al., 1987, and references therein) (Fig. 2).

The Toca da Moura volcano-sedimentary complex is mainly composed of pelites (i.e., Xistinhos; Teixeira, 1944; Fig. 3a) and greywackes associated with andesite to rhyolite volcanic rocks (lava flow and tuffs; Fig. 3c-e), andesitic basalt, chert layers (Gonçalves and Carvalhosa, 1984), and a few olistoliths of basalt and limestone. Siliciclastic rocks contain well-preserved in situ palynomorph assemblages of Tournaisian to Visean age and reworked palynomorphs ranging in age from the middle Cambrian to the early Tournaisian (Pereira et al., 2006; Lopes et al., 2014). Based on geochemical information, this volcanism was interpreted by Santos et al. (1987) as deriving from calc-alkaline magma produced in a continental magmatic arc. A stratigraphic correlation was established between the Toca da Moura volcanosedimentary complex and the Cabrela volcano-sedimentary 


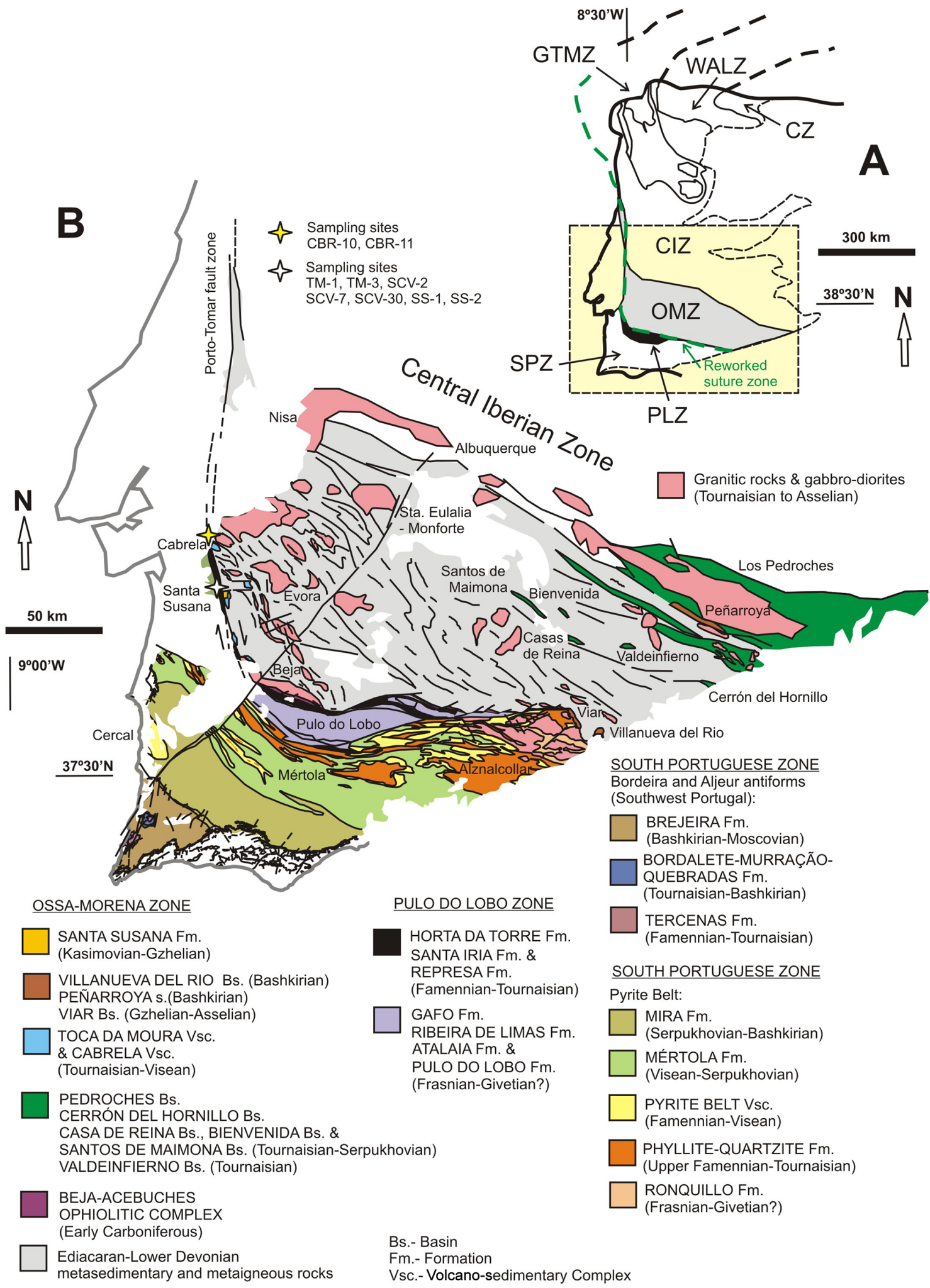

Figure 1. (a) Inset with location of SW Iberia in the Iberian Variscan belt with regional distribution of the main Paleozoic terranes: CIZ - Central Iberian Zone; CZ - Cantabrian Zone; GTMZ - Galicia-Trás-os-Montes Zone; OMZ - Ossa-Morena Zone; PLZ - Pulo do Lobo Zone; SPZ - South Portuguese Zone; and WALZ - West Asturian-Leonese Zone. (b) Simplified geological map of SW Iberia showing the South Portuguese, Pulo do Lobo, and Ossa-Morena zones (modified from Pereira et al., 2017a, 2019, and references therein; Quesada and Oliveira, 2019). 


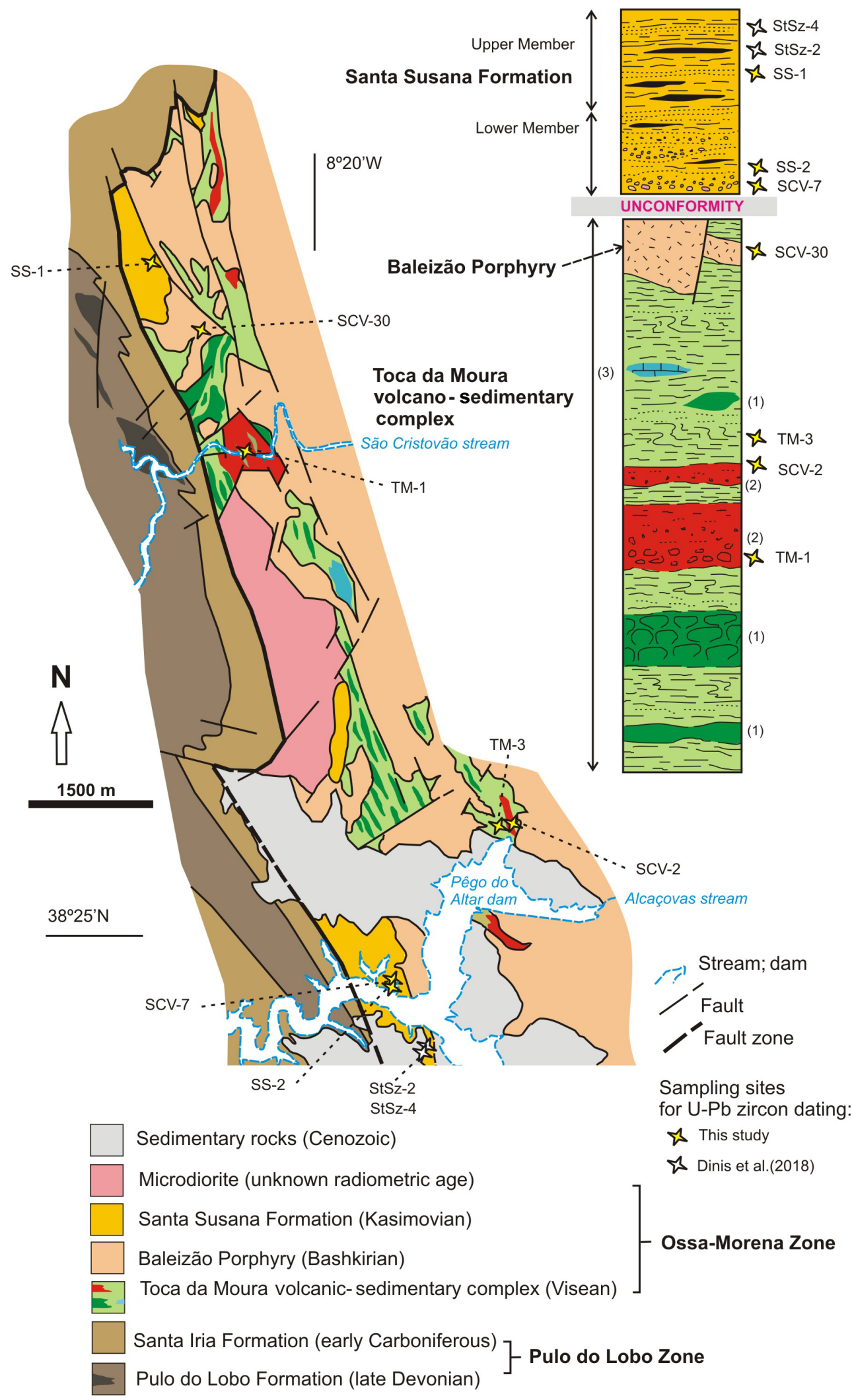

Figure 2. Simplified geological map and schematic stratigraphy of the Santa Susana-São Cristovão region (Ossa-Morena Zone; modified from Gonçalves and Carvalhosa, 1984; Machado et al., 2012). Sampling locations of the Carboniferous sedimentary and igneous rocks used for geochronology are indicated with yellow stars. 
complex (Pereira et al., 2006), which is located $15 \mathrm{~km}$ to the NW in the Évora Massif (Pereira et al., 2007, 2012a) (Fig. 1b). The presence of variable-scale soft-sediment structures (i.e., slumps, intraclast conglomerates, and olistoliths) in both complexes indicates gravity-induced instability during marine sedimentation. Detrital zircon ages of a siliciclastic rock from the Cabrela volcano-sedimentary complex interbedded with silicic tuffs (Fig. 3f) are mainly middle to late Devonian (82\%) and early Carboniferous (14\%) and also include a few older grains (sample OM-200 from Pereira et al., 2012a).

The Santa Susana Formation (i.e., Santa Susana Basin; Domingos et al., 1983; Quesada et al., 1990; Oliveira et al., 1991) siliciclastic rocks that outcrop along a narrow, NNW-SSE-trending discontinuous band, which is $0.1-5 \mathrm{~km}$ wide and $12 \mathrm{~km}$ long, overlie unconformably the Baleizão porphyry and the Toca da Moura volcano-sedimentary complexes (Fig. 2), forming the geological contact between these stratigraphic units often defined by faults (Gonçalves and Carvalhosa, 1984). The Santa Susana Formation is divided into two members (Machado et al., 2012, and references therein): (i) the lower member is mainly composed of coarsegrained sandstone and conglomerate beds (Fig. 4a-d), and these conglomerates include pebbles and cobbles of silicic porphyry, rhyolite, andesite, basalt, granite, felsic tuff, pelite, sandstone, greywacke, quartzite, phyllite, chert, and quartz (Fig. 4e, f); (ii) the upper member represents a repetitive sequence of alternating beds of pelite and sandstone interbedded with coal seams and a few beds of conglomerate (Fig. 2). These terrestrial deposits were most probably deposited in an alluvial, fluvial-to-fluvial, and/or lacustrine (floodplain lakes and/or abandoned channels with abundant vegetation) system (Machado et al., 2012, and references therein). The plant fossils identified in the siliciclastic rocks of the Santa Susana Formation indicate a Moscovian-Kasimovian biostratigraphic age (Wagner and Lemos de Sousa, 1983). Pelitic beds from the upper member include palynomorph assemblages assigned a Kasimovian age (Machado et al., 2012). Palynomorphs ranging in age from the middle Cambrian to the early Moscovian were also found in siliciclastic rocks of the Santa Susana Formation sampled from a borehole at a depth of around $400 \mathrm{~m}$ (Lopes et al., 2014). Detrital zircon ages from upper member sandstones (Dinis et al., 2018) are mainly distributed over the Devonian-Carboniferous $(41 \%-51 \%)$, Paleoproterozoic (23\%-30\%), and Ediacaran-Cryogenian (16\%$23 \%$ ) groups, as well as a few Stenian-Tonian and Archean grains.

\section{Rational and analytical methods}

$\mathrm{U}-\mathrm{Pb}$ geochronology of detrital zircon from siliciclastic rocks has been extensively used in stratigraphic correlation studies for estimating the maximum depositional age and in- vestigating the provenance of sedimentary sequences (Fedo et al., 2003; Dickinson and Gehrels, 2009). The youngest detrital zircon grains found in siliciclastic rock commonly provide useful information about depositional age, especially in areas that experienced active volcanism during sediment accumulation (Gehrels, 2014). The maximum depositional age obtained for siliciclastic rock is often not necessarily coincident with the biostratigraphic age as defined by key fossil assemblages (Pereira et al., 2019). Therefore, in order to overcome any doubt about the true age of deposition, it is desirable that volcanic rocks interstratified with fossiliferous siliciclastic rocks should be dated (Fedo et al., 2003; Bowring et al., 2006). Furthermore, the application of zircon U-Pb geochronology to volcano-sedimentary and sedimentary sequences, which are separated by unconformities by means of the comparative analysis of their age populations, may be useful for estimating time intervals and revealing changes in provenance. Volcanic rocks that lie beneath or overlie sedimentary sequences and unconformities can provide maximum and minimum ages, respectively. When detrital zircon geochronology is linked to the geochronology of crosscutting younger igneous rocks, then both a maximum and minimum age bracket for deposition can be determined (Fedo et al., 2003).

In this study, SHRIMP U-Pb analyses were performed for the first time on magmatic zircon from two tuffs from the Toca da Moura volcano-sedimentary complex (TM-1 and SCV-2; Fig. 3c, d), one tuff from the Cabrela volcanosedimentary complex (CBR-12), one from the Baleizão silicic porphyry (SCV-30; Fig. 3b), and a cobble of granite (SCV-7; Fig. 4e) found in a conglomerate from the lower member of the Santa Susana Formation. Estimations of the crystallization age of samples SCV-2, TM-1, and CBR12 (syndepositional volcanism) and sample SCV-30 (postdepositional) were used to validate the Tournaisian-Visean biostratigraphic age previously attributed to the Toca da Moura and Cabrela volcano-sedimentary complexes based on palynological assemblages (Pereira et al., 2006; Lopes et al., 2014). The presence of granite cobbles and pebbles in conglomerate layers from the lower Santa Susana Formation indicates denudation and recycling of a crystalline basement involving granite whose age is unknown. The dating of the granite cobble (sample SCV-7) is useful for discussing provenance and estimating the maximum depositional age of the Santa Susana conglomerate. In addition, LA-ICP-MS U-Pb analyses were performed on detrital zircon grains from two samples of sandstone from the upper and lower members of the Santa Susana Formation (samples SS-1 and SS-2, respectively; Fig. 5g, h) and a sample of pelite from the Toca da Moura volcano-sedimentary complex (sample TM-3; Fig. 5e). These new U-Pb data are useful for discussing provenance and determining the maximum depositional ages of the two sedimentary sequences separated by an intra-Carboniferous unconformity. Sample locations in the Santa Susana-São Cristovão region are indi- 

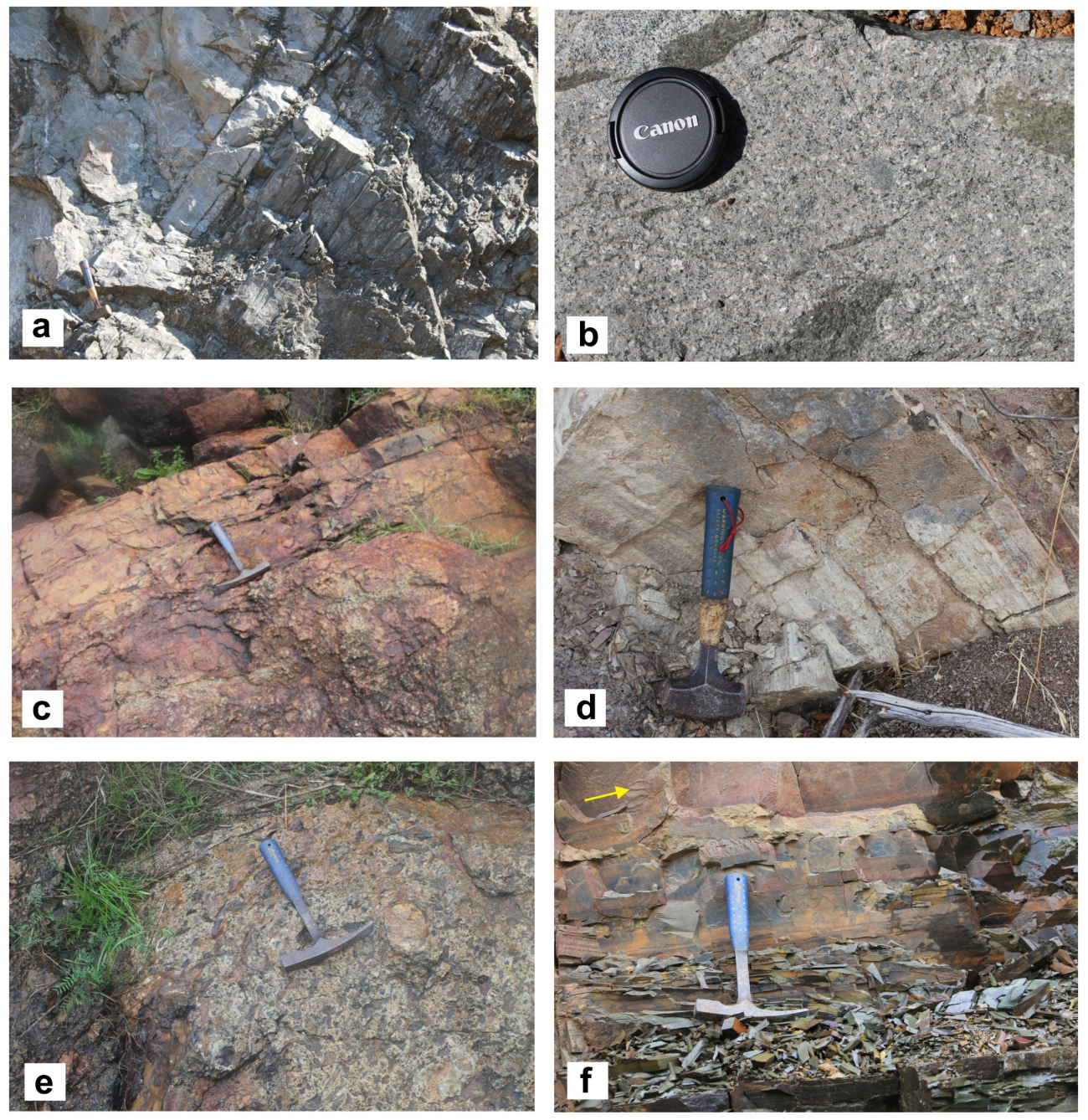

Figure 3. Photographs of the Carboniferous igneous rocks of the Santa Susana-São Cristovão region: (a) Baleizão porphyry intrusive contact (yellow arrow) with siliciclastic rocks of the Toca da Moura volcano-sedimentary complex; (b) Baleizão porphyry; (c, d) rhyolitic tuffs of the Toca da Moura volcano-sedimentary complex; (e) volcanic breccia with fragments of siltstone (black) and rhyolite (yellow) at the base of the silicic tuffs of the Toca da Moura volcano-sedimentary complex; and (f) silicic volcanic rock interbedded with siltstones of the Cabrela volcano-sedimentary complex.

cated in Fig. 2. Finally, detrital zircon grains of siliciclastic rock from the Cabrela volcano-sedimentary complex (sample CBR-11; Fig. 5f; equivalent to sample OM-200 of Pereira et al., 2012a) were analyzed to test for the existence of preDevonian ages. The new $\mathrm{U}-\mathrm{Pb}$ results obtained in the present study are compared with previously reported age spectra for pre-Kasimovian siliciclastic rocks from the OMZ, PLZ, and SPZ siliciclastic sequences of SW Iberia using statistical tools.

Zircon grains for $\mathrm{U}-\mathrm{Pb}$ geochronology were selected using traditional techniques: density separation with a Wilfley table (Universidad Complutense de Madrid, Spain) and also a granulometric separation using sieves with a mesh size of less than $500 \mu \mathrm{m}$, density (panning) separation procedures, and mineral identification using a binocular lens and prepara- tion of epoxy resin mounts with zircon grains (Universidade de Évora, Portugal). U-Pb measurements were obtained at IBERSIMS (Universidad de Granada, Spain) using SHRIMP and also at the Senckenberg Naturhistorische Sammlungen Dresden (Museum für Mineralogie und Geologie, Germany) using LA-ICP-MS. U-Pb measurements using SHRIMP and LA-ICP-MS followed the procedures previously described by Dias da Silva et al. (2018) and Pereira et al. (2012a), respectively. $\mathrm{U}-\mathrm{Pb}$ results are listed in Tables $\mathrm{S} 1$ and $\mathrm{S} 2$ in the Supplement. Concordia curves and weighted average means were obtained using Isoplot 4 (Ludwig, 2003) (Figs. 6 and 7). Kernel density estimation (KDE) diagrams were produced with $90 \%-110 \%$ concordant ${ }^{206} \mathrm{~Pb} /{ }^{238} \mathrm{U}$ ages for grains younger than $1.0 \mathrm{Ga}$ and ${ }^{207} \mathrm{~Pb} /{ }^{206} \mathrm{~Pb}$ ages for older grains (for further details, see Frei and Gerdes, 2009) using IsoplotR 

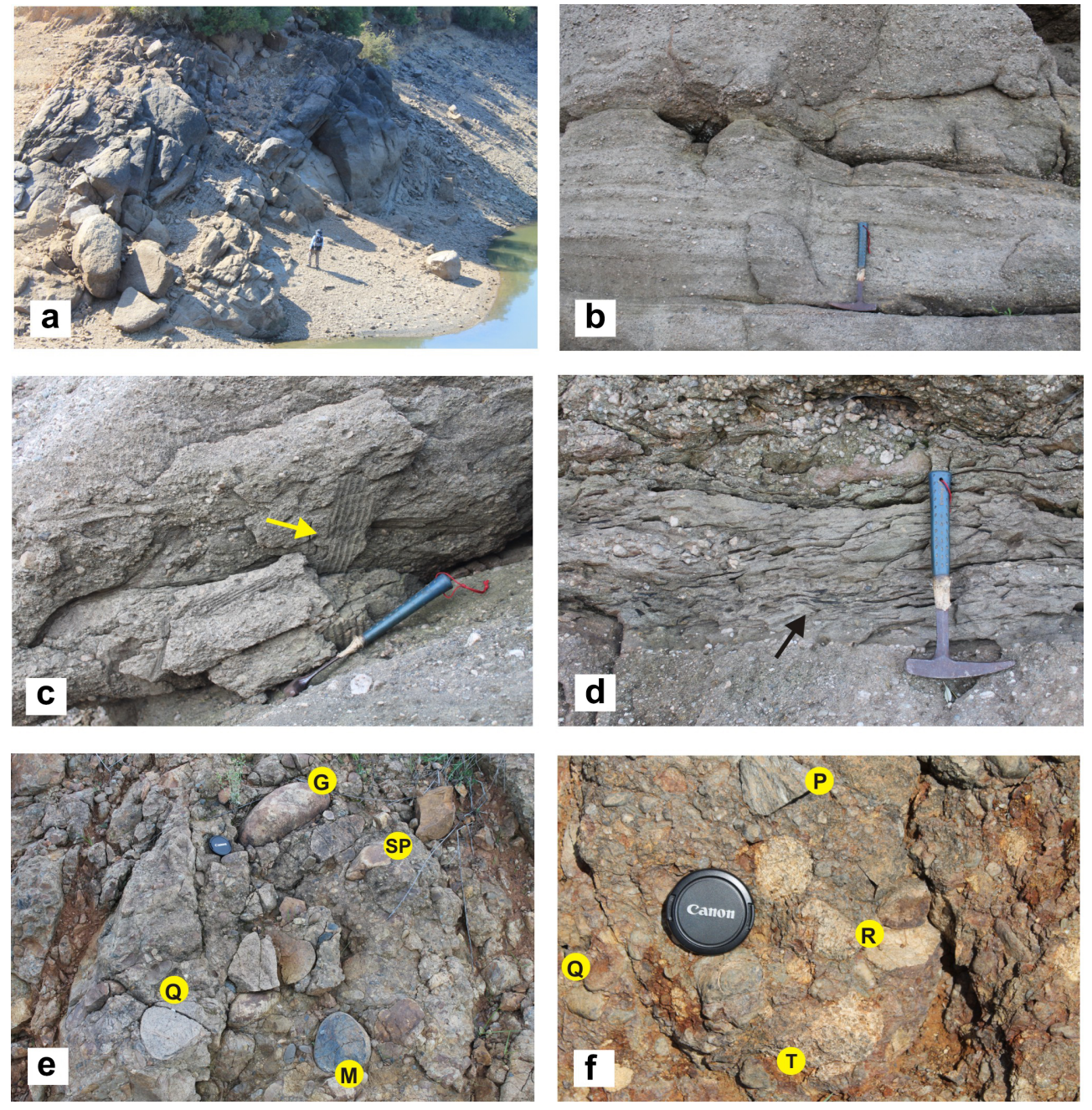

Figure 4. Photographs of the Carboniferous sedimentary rocks of the Santa Susana Formation lower member: (a) view of dipping meter-thick beds of medium-coarse grained sandstone intercalated with conglomerate; (b) planar-bedded coarse-grained sandstone; (c) plant imprints in sandstone; (d) conglomerate with cobbles and pebbles of granite $(\mathrm{G})$, quartzite $(\mathrm{Q})$, silicic porphyry (SP), and mafic volcanic rock (M); (e, f) conglomerate with pebbles of rhyolite (R), phyllite (P), felsic tuff (T), and quartzite (Q).

(Vermeesch, 2018) (Fig. 8a, b). Cathodoluminescence imaging was performed at TU Bergakademie Freiberg (Germany) and at IBERSIMS.

The $\mathrm{K}-\mathrm{S}$ test and the multidimensional scaling (MDS) technique were used in conjunction to compare populations of detrital zircon $\mathrm{U}-\mathrm{Pb}$ ages obtained from the Carboniferous siliciclastic rocks of the Santa Susana-São Cristovão region using a method designed for a recent study of the provenance of Triassic sandstones (Gama et al., 2020, and references therein). The $\mathrm{K}-\mathrm{S}$ test is a nonparametric statistical tool that has been successfully used for the comparison of two populations of detrital zircon $\mathrm{U}-\mathrm{Pb}$ ages by evaluating whether they are significantly different, i.e., whether zircon age populations correlate with a similar source or not, regardless of whether they are of different sizes, while including at least 20 measurements (DeGraaff-Surpless et al., 2003). The proba- bility of the observed maximum vertical difference between the cumulative probability curves ( $D$ value) being unrelated to age differences between the two detrital zircon populations is given by a $P$ value corresponding to a confidence interval of $95 \%$ (Barbeau et al., 2009; Guynn and Gehrels, 2010) (Fig. $\mathrm{S} 1$ in the Supplement). High $P$ values and low $D$ values indicate that the observed difference between the two detrital zircon populations may be explained by the existence of common sources (Gama et al., 2020, and references therein). $\mathrm{K}-\mathrm{S}$ analyses were carried out using an Excel spreadsheet as described in Guynn and Gehrels (2010). The MDS technique provides a means for the comparison of samples based on quantified pairwise comparisons of their detrital zircon ages and is extremely useful for visualizing the degree of similarity between samples in two dimensions; i.e., greater distances between samples represent a greater degree of dissim- 

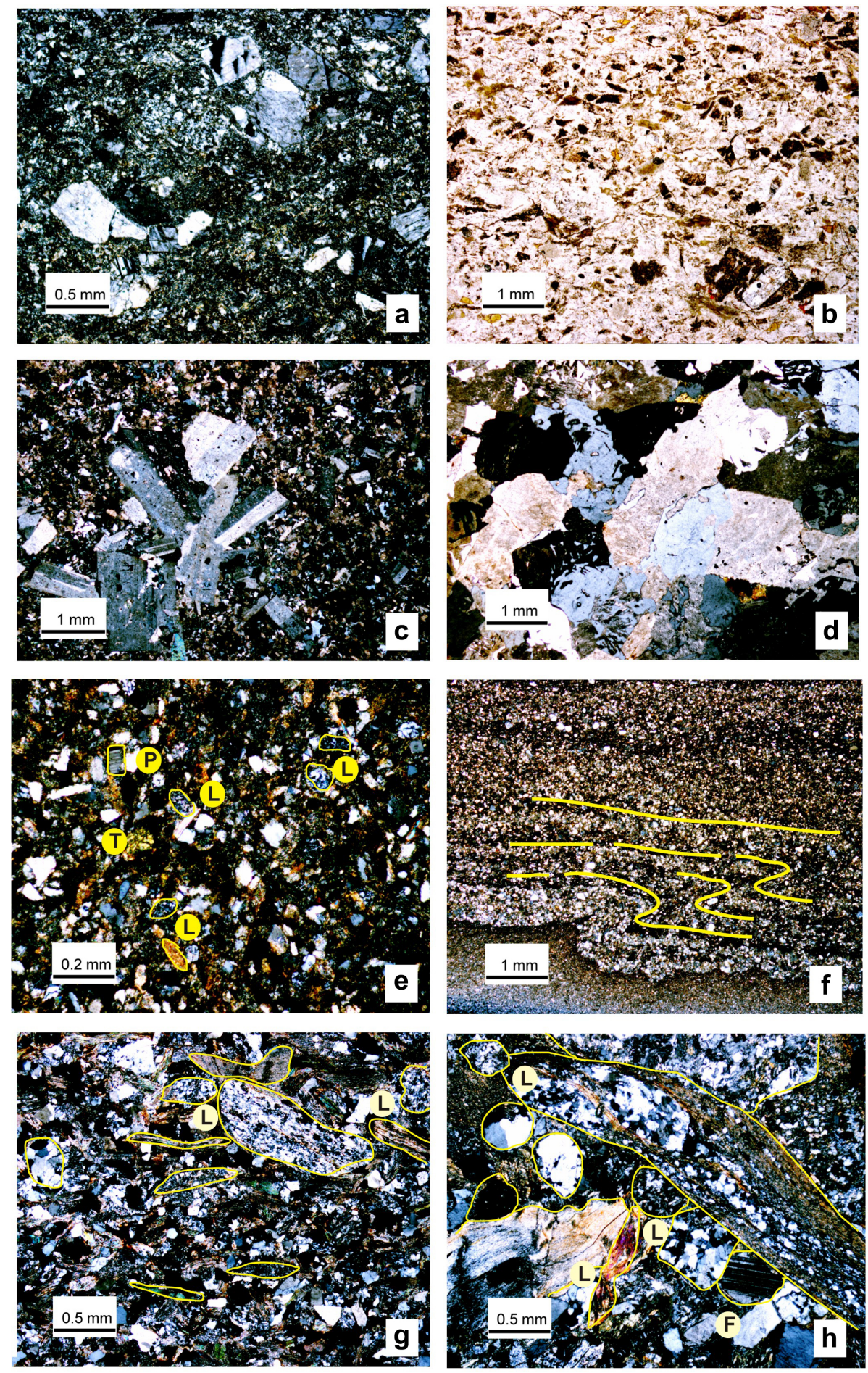

Figure 5. Petrographic images of the Carboniferous sedimentary and igneous rocks of the Santa Susana-São Cristovão region: (a) rhyoliticrhyodacite tuff of the Toca da Moura volcano-sedimentary complex showing quartz and feldspar phenocrysts enclosed in an ash matrix; (b) rhyolitic tuff showing flattened dark-brown millimeter-sized pumice and lithoclasts enclosed in an ash matrix; (c) porphyritic texture of the Baleizão rhyodacite-rhyolite characterized by quartz, plagioclase, K-feldspar, biotite, and amphibole phenocryst embedded in a finegrained silicic matrix; (d) cobble of fine-grained granite showing graphic intergrowths of quartz and alkali feldspar, found in conglomerate from the Santa Susana Formation; (e) siltstone of the Toca da Moura volcano-sedimentary complex mostly composed of quartz grains and a few grains of plagioclase (P), tourmaline (T), and rock fragments (L); (f) siltstone of the Cabrela volcano-sedimentary complex showing fining upward grading and a slump fold; and $(\mathbf{g}, \mathbf{h})$ sandstones from the Santa Susana Formation with a high percentage of lithoclasts (L) and feldspar (F). 

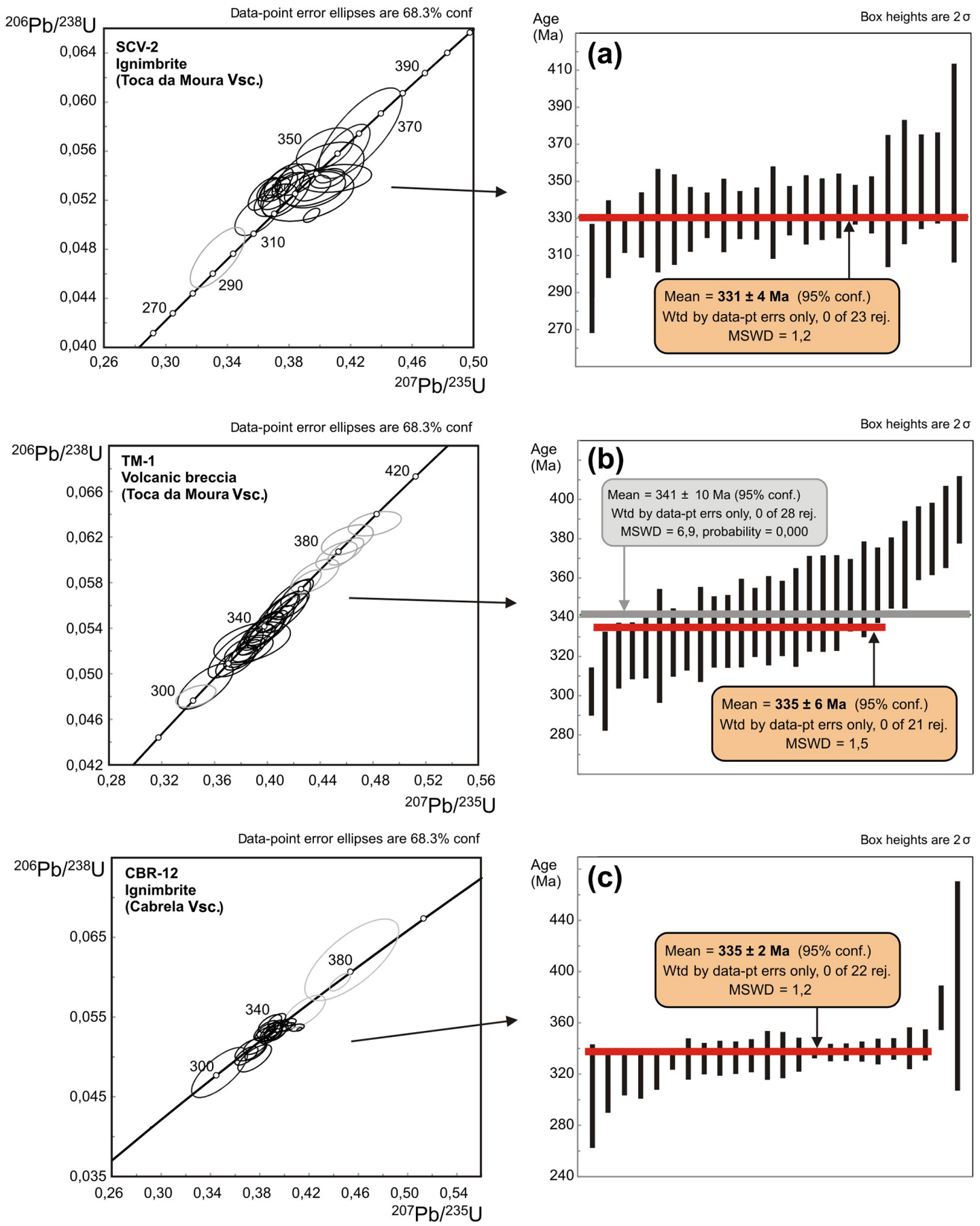

Figure 6. Concordia diagrams and weighted mean of ${ }^{206} \mathrm{~Pb} /{ }^{238} \mathrm{U}$ ages of analyzed zircon grains extracted from silicic volcanic rocks of the Toca da Moura and Cabrela volcano-sedimentary complexes.

ilarity between points on MDS diagrams (Vermeesch, 2013; Spencer et al., 2015; Wissink et al., 2018) (Fig. 9). MDS diagrams were produced using IsoplotR (Vermeesch, 2018).

\section{$4 \mathrm{U}-\mathrm{Pb}$ geochronology: results}

\subsection{Volcanic silicic rocks of the Toca da Moura and Cabrela volcano-sedimentary complexes}

Sample SCV-2 is a fine-grained banded rhyolitic tuff consisting of quartz and $\mathrm{K}$-feldspar phenocrysts and lithoclasts 
(a)
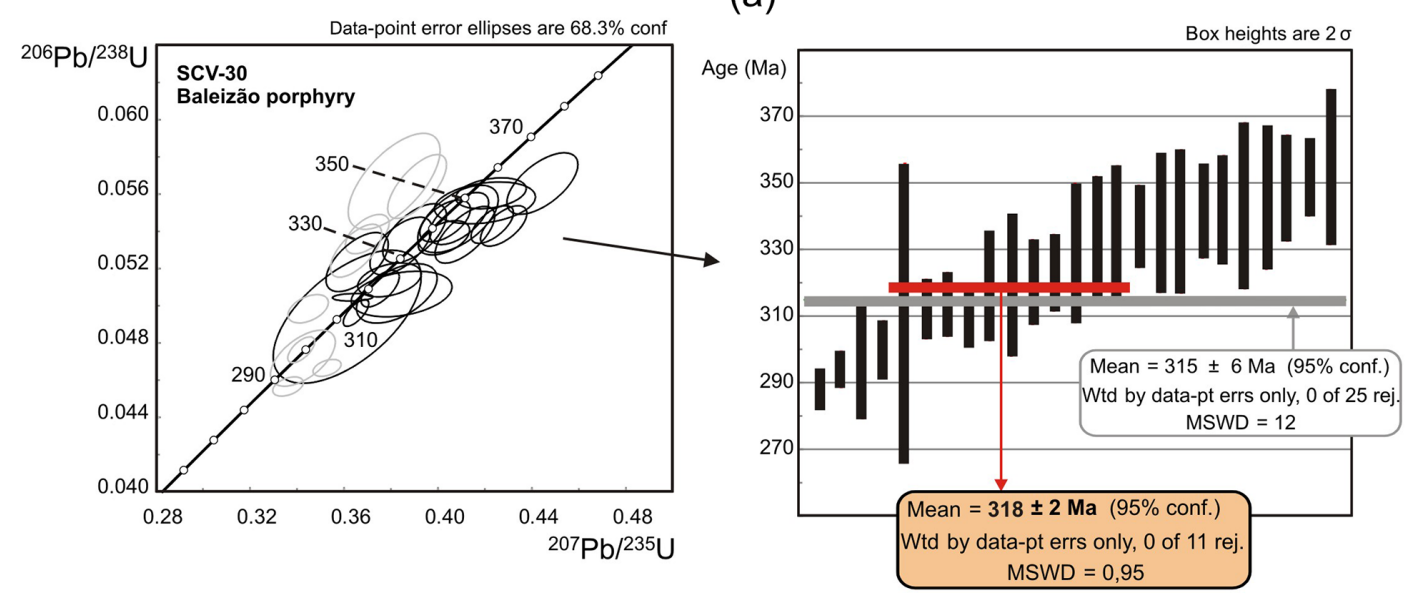

(b)
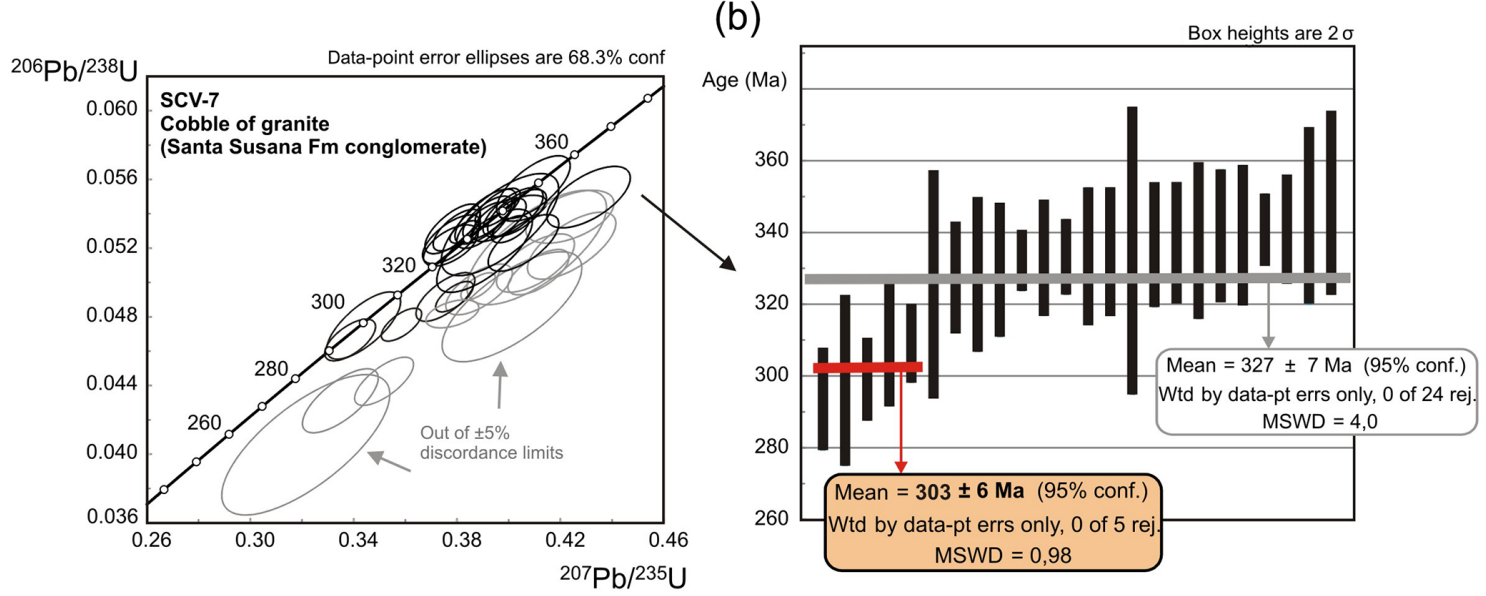

Figure 7. Concordia diagrams and weighted mean of ${ }^{206} \mathrm{~Pb} /{ }^{238} \mathrm{U}$ ages of analyzed zircon grains of (a) the Baleizão porphyry and (b) the cobble of granite found in conglomerate from the Santa Susana Formation.

of varying size and shape (less than $1 \mathrm{~mm}$ in diameter) dispersed in an ash matrix (Fig. 5a). Zircon grains appear as stubby to elongated euhedral prisms $(50-150 \mu \mathrm{m}$ in diameter), mostly showing oscillatory concentric zoning growing on distinct cores or as simple crystals. There are some dark inclusions, unzoned patches, and transgressive variable luminescence and embayments. A total of $44 \mathrm{U}-\mathrm{Th}-\mathrm{Pb}$ SHRIMP analyses of 44 grains yielded $U$ contents ranging from 262 to $628 \mathrm{ppm}$. A group of 23 grains with ${ }^{206} \mathrm{~Pb} /{ }^{238} \mathrm{U}$ ages (discordance $\leq 5 \%$ ) yielded a weighted mean ${ }^{208} \mathrm{~Pb} /{ }^{238} \mathrm{U}$ age of $331 \pm 4 \mathrm{Ma}$ (mean square of weighted deviates; MSWD = 1.2; Fig. 6a), which probably represents the crystallization age of tuff.

Sample TM-1 is a fine-grained banded rhyolitic tuff consisting of quartz, K-feldspar, and biotite phenocrysts, flattened dark-brown pumice (i.e., fiamme), and lithoclasts (less than $1 \mathrm{~mm}$ in diameter) enclosed in an ash matrix (Fig. 5b). The zircon population is characterized by stubby euhedralto subeuhedral-sized (30-100 $\mu \mathrm{m}$ in diameter) grains. Magmatic grains are either simple with concentric zoning or com- posite showing variable luminescence cores with concentric zoning, no zoning, or banded zoning. These cores are surrounded by overgrowths with concentric zoning and are occasionally diffuse or unzoned. A total of $120 \mathrm{U}-\mathrm{Th}-\mathrm{Pb} \mathrm{LA}-$ ICP-MS analyses yielded $U$ contents ranging from 87 to $4136 \mathrm{ppm}$. There are $28{ }^{206} \mathrm{~Pb} /{ }^{238} \mathrm{U}$ ages $(90 \%-110 \%$ of concordance) that yielded a weighted mean ${ }^{208} \mathrm{~Pb} /{ }^{238} \mathrm{U}$ age of $341 \pm 10 \mathrm{Ma}$ with a very poor fit (MSWD $=6.9$; Fig. $6 \mathrm{~b}$ ) as indicated by the scattering of ages along the Concordia curve. A coherent group of 21 grains with ${ }^{206} \mathrm{~Pb} /{ }^{238} \mathrm{U}$ ages yielded a weighted mean ${ }^{208} \mathrm{~Pb} /{ }^{238} \mathrm{U}$ age of $335 \pm 6 \mathrm{Ma}$ (MSWD $=1.5$; Fig. $6 \mathrm{~b}$ ), providing the best age estimate for the volcanic rock (Fig. 6b). The youngest zircon grain (ca. $302 \mathrm{Ma}$ ) probably experienced $\mathrm{Pb}$ loss. The six oldest zircon grains present Paleoproterozoic (ca. $2 \mathrm{Ga}$ ), Neoproterozoic (ca. $715 \mathrm{Ma}$ ), and Devonian (ca. 395-378 Ma) ages, suggesting inheritance.

Sample CBR-12 is a fine-grained rhyolitic rock in which feldspar and quartz phenocrysts and lithic fragments occur embedded in an altered, very fine-grained matrix of quartz, 

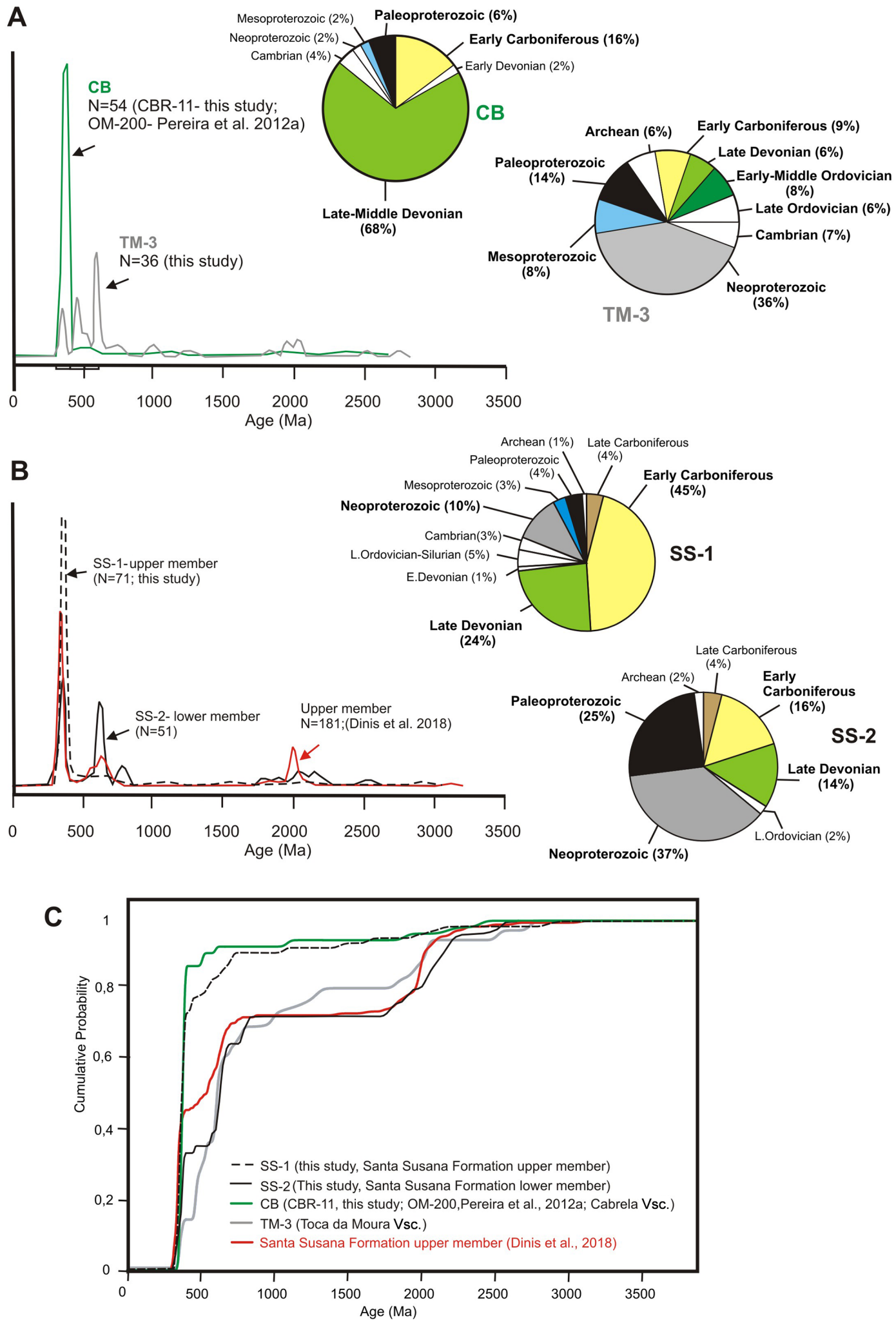

Figure 8. Pie diagrams and kernel density estimation (KDE) with U-Pb detrital zircon ages of siliciclastic rocks from (a) the Toca da Moura (TM-3; this study) and Cabrela (CB; CBR-11; this study; OM-200; Pereira et al., 2012a) volcano-sedimentary complexes and (b) the Santa Susana Formation (SS-1 and SS-2; this study; SS upper member, StSz2, and StSz4; Dinis et al., 2018). (c) U-Pb age cumulative frequency plots applied to the U-Pb ages (90\%-110\% concordance) of detrital zircon grains from the Toca da Moura and Cabrela volcano-sedimentary complexes and the Santa Susana Formation. 
sericite, and chlorite, including devitrified shards. Zircon (40-150 $\mu \mathrm{m}$ in diameter) appears as stubby to elongated euhedral prisms, mostly showing oscillatory concentric zoning and sometimes being disturbed by inclusions. A few crystals show banded zoning or are diffuse or unzoned. A total of 32 analyses were performed on this silicic volcanic rock yielding $\mathrm{U}$ contents ranging from 288 to $2587 \mathrm{ppm}$. A total of 22 analyses with discordance $\leq 5 \%$ yielded a weighted mean ${ }^{208} \mathrm{~Pb} /{ }^{238} \mathrm{Th}$ age of $335 \pm 2 \mathrm{Ma}(\mathrm{MSWD}=1.2$; Fig. $6 \mathrm{c}$ ). The oldest two grains yielding ${ }^{206} \mathrm{~Pb} /{ }^{238} \mathrm{U}$ ages of ca. 389 and $371 \mathrm{Ma}$ are interpreted as representing xenocrysts.

\subsection{Baleizão porphyry}

Sample SCV-30 is a porphyritic rhyodacite-rhyolite consisting of quartz, plagioclase, K-feldspar, biotite, and amphibole phenocryst (less than $3 \mathrm{~mm}$ in diameter) embedded in a finegrained silicic matrix (Fig. 5c). The zircon population contains grains (30-140 $\mu \mathrm{m}$ in diameter) from subrounded subhedral to prismatic euhedral. Prisms are equant to moderately elongate showing a simple internal structure characterized by concentric and sector zoning to unzoned. A concentric zoned or unzoned rim surrounds unzoned cores of a few composite grains. A total of $37 \mathrm{U}-\mathrm{Th}-\mathrm{Pb}$ SHRIMP analyses for sample SCV-30 yielded U contents ranging from 74 to $4290 \mathrm{ppm}$. For zircon, 25 analyses were obtained with discordance $\leq$ $5 \%$, distributed along the concordia curve from ca. 355 to $288 \mathrm{Ma}$, and yielded a weighted mean ${ }^{208} \mathrm{~Pb} /{ }^{238} \mathrm{Th}$ age of $315 \pm 6 \mathrm{Ma}$ (MSWD = 12; Fig. 7a). Some of the spread observed could be due to the presence of inheritance. The oldest 10 grains yielding ${ }^{206} \mathrm{~Pb} /{ }^{238} \mathrm{U}$ ages of ca. $355-337$ Ma probably represent xenocrysts derived from the Toca da Moura volcano-sedimentary complex. The 11 grains in the age range ca. $334-311$ Ma yielded a weighted mean ${ }^{208} \mathrm{~Pb} /{ }^{238} \mathrm{U}$ age of $318 \pm 2 \mathrm{Ma}$ (MSWD $=0.95$; Fig. 7a), which is regarded as the best estimate for the crystallization age of subvolcanic silicic rock.

\subsection{Cobble of granite found in a conglomerate from the Santa Susana Formation}

Sample SCV-7 is a cobble $(20 \mathrm{~cm}$ in diameter $)$ of pinkish medium-grained granite consisting of quartz, alkali feldspar, and biotite (Fig. 5d). Most zircons are stubby and elongated subeuhedral to euhedral prisms (80 to $150 \mu \mathrm{m}$ in diameter). Morphologically, zircon grains are mostly simple, showing concentric zoning, sector zoning, or no zoning, and a few are composite with irregular and unzoned small cores surrounded by a rim with concentric zoning. In total, $40 \mathrm{U}-\mathrm{Th}-\mathrm{Pb}$ SHRIMP analyses were performed on sample SCV-7 with U content ranging from 348 to $3177 \mathrm{ppm}$. Of this total number of analyses, $24 \mathrm{U}-\mathrm{Pb}$ ages with discordance $\leq 5 \%$, scattered along the concordia curve from ca. 349 to $294 \mathrm{Ma}$, yielded a weighted mean ${ }^{206} \mathrm{~Pb} /{ }^{238} \mathrm{U}$ age of $327 \pm 7 \mathrm{Ma}(\mathrm{MSWD}=4$; Fig. $7 \mathrm{~b})$. A group of six zir- con grains in the age range of ca. 309-294 Ma yielded a weighted mean ${ }^{206} \mathrm{~Pb} /{ }^{238} \mathrm{U}$ age of $303 \pm 6 \mathrm{Ma}$ (MSWD = 0.98; Fig. 7b), which is taken as the probable crystallization age of the granite. The remaining 19 zircon grains yielded ${ }^{206} \mathrm{~Pb} /{ }^{238} \mathrm{U}$ ages of ca. $349-326 \mathrm{Ma}$, suggesting inheritance.

\subsection{Siliciclastic rocks from the Toca da Moura and Cabrela volcano-sedimentary complexes}

Sample TM-3 is a laminated, poorly sorted siltstone with quartz-rich silt layers containing feldspar and tourmaline grains and lithoclasts (Fig. 5e), which are intercalated with darker layers of clay. The zircon population is mostly characterized by stubby to elongated prismatic small grains (less than $100 \mu \mathrm{m}$ in diameter). It includes simple and composite zircons showing concentric, sector, and banded zoning. Of a total of 82 U-Th-Pb LA-ICP-MS analyses with U contents ranging from 19 to $4630 \mathrm{ppm}, 36$ zircon grains yield $90 \%-110 \%$ concordance. The number of grains of sample TM-1 does not conform to the minimum of $60-100$ grains often used in provenance studies (Vermeesch, 2004), and therefore percentages based on the proportions of ages need to be interpreted with caution. The Paleozoic population of detrital zircon $(36 \%)$ includes early Carboniferous (9\%; ca. 353,349 , and $340 \mathrm{Ma}$ ), Ordovician (14\%; ca. 476$456 \mathrm{Ma}$ ), Cambrian (7\%; ca. 531-500 Ma), and late Devonian (6\%; ca. 369 and $362 \mathrm{Ma}$ ) grains (Fig. 8a). The Precambrian population $(64 \%)$ is predominantly Neoproterozoic ( $36 \%$; ca. $983-587 \mathrm{Ma}$ ) but also includes Paleoproterozoic (14\%; ca. 2-1.8 Ga), Mesoproterozoic (8\%; ca. 1.3$1 \mathrm{Ga}$ ), and Archean (6\%; ca. 2.7-2.5 Ga) grains. The three youngest zircon grains (ca. 353-340 Ma) yielded a maximum depositional age of ca. $348 \mathrm{Ma}$ (Tournaisian), which is in accordance with the sedimentary age inferred from biostratigraphic constraints (late Tournaisian to middle to late Visean; Pereira et al., 2006; Lopes et al., 2014).

Sample CBR-11 is a fine-grained poorly to moderately sorted siltstone consisting predominantly of quartz and a few feldspar grains and lithoclasts enclosed in silt-clay-sized particles (Fig. 5g). Most zircon grains are small (less than $100 \mu \mathrm{m}$ in diameter) and euhedral to subeuhedral. They are simple grains (short, stubby to equant prisms) with oscillatory concentric and banded zoning, and only a few are composite grains with rounded cores. Of a total of $20 \mathrm{U}-\mathrm{Th}-\mathrm{Pb}$ LA-ICP-MS analyses with U contents ranging from 54 to $1379 \mathrm{ppm}, 10$ grains yielded $90 \%-110 \%$ of concordance. Five grains are Paleozoic (Carboniferous: ca. 359, 351, and $346 \mathrm{Ma}$; Cambrian: ca. 514 and $511 \mathrm{Ma}$ ) and five are Precambrian (Paleoproterozoic: ca. 2.4, 2.1, and 1.8 Ga; Mesoproterozoic: $1 \mathrm{Ga}$; Neoproterozoic: ca. $603 \mathrm{Ma}$ ). By combining our new data with those from sample OM-200 (Pereira et al., 2012a) collected from the same quarry as sample CBR11 , it was found that the detrital zircon population (CB, $N=54$; Fig. 8 a) is largely dominated by Paleozoic grains (90\%): late to middle Devonian (68\%), early Carboniferous 
(15\%), Cambrian (4\%), and early Devonian (2\%) grains, being distinct from sample TM-3 described above (Fig. 8a). The number of grains of sample CB $(N=54)$, despite being larger than that of sample TM-1, does not conform to the minimum of $60-100$ grains, and therefore the proportions of ages obtained also need to be interpreted with caution. The youngest zircon population $(N=5)$, ranging from ca. 353 to $346 \mathrm{Ma}$, suggests a Tournaisian maximum depositional age which is slightly older than the sedimentary age inferred from biostratigraphic constraints (late Tournaisian to middle to late Visean; Pereira et al., 2006).

\subsection{Siliciclastic rocks from the Santa Susana Formation}

Sample SS-2 represents medium- to coarse-grained, poorly sorted sandstone. It is mainly composed of lithoclasts (siltstone, mudstone, quartzite, phyllite, rhyolite, basalt) and quartz grains but also includes muscovite and feldspar grains (Fig. $5 \mathrm{~g}$ ). The zircon population is mostly characterized by stubby to prismatic and subrounded to subangular grains (120-300 $\mu \mathrm{m}$ in diameter). Morphologically simple and composite grains were found. Cathodoluminescence imaging shows that most zircon grains have concentric oscillatory zoning or irregular zoning, or they are banded or unzoned. In total, $153 \mathrm{U}-\mathrm{Th}-\mathrm{Pb}$ LA-ICP-MS analyses were performed on detrital zircon grains. They show $\mathrm{U}$ contents ranging from 15 to $6158 \mathrm{ppm}$. A population with 51 grains yielding $\mathrm{U}_{-}$ $\mathrm{Pb}$ ages with $90 \%-110 \%$ concordance (Fig. 8b) is dominated by Precambrian ages (64\%): Neoproterozoic (37\%; ca. $801-551 \mathrm{Ma})$, Paleoproterozoic (25\%; ca. 2.4-1.6 Ga), and Neoarchean (2\%; ca. $2.5 \mathrm{Ga})$. The Paleozoic grains (36\%) are Carboniferous (20\%; ca. 359-303 Ma), late Devonian (14\%; ca. 378-362 Ma), and early Ordovician (2\%; ca. $447 \mathrm{Ma}$ ). The youngest two grains ( $303 \pm 4 \mathrm{Ma}$; KasimovianGzhelian) are slightly younger than the sedimentary age inferred from biostratigraphic constraints (middle Moscovian to Kasimovian; Lemos de Sousa and Wagner, 1983; Machado et al., 2012; Lopes et al., 2014).

Sample SS-1 represents a very coarse-grained sandstone consisting of rounded to subangular mono- and polycrystalline quartz, feldspar, and muscovite grains and a wide variety of lithoclasts (chert, phyllite, rhyolite, siltstone, and sandstone; Fig. 5h). Zircon grains are rounded to subangular, stubby, and elongated prisms (less than $280 \mu \mathrm{m}$ in diameter). The zircon population includes simple grains with oscillatory concentric, banded, and sector zoning and composite grains with cores with distinct internal morphologies surrounded by variable width rims. A total of 150 U-Th$\mathrm{Pb}$ LA-ICP-MS analyses performed on detrital zircon grains yielded U contents ranging from 24 to $9819 \mathrm{ppm}$. A group of 71 grains yielding $\mathrm{U}-\mathrm{Pb}$ ages with $90 \%-110 \%$ concordance are dominated by Paleozoic ages (82\%), predominantly made up of Carboniferous (49\%; ca. 358-315 Ma) and Devonian (25\%; ca. 389-359 Ma) grains and a few late Ordovician-Silurian (5\%; ca. 434, 429, and 425 Ma) and
Cambrian (3\%; ca. 533 and $491 \mathrm{Ma}$ ) grains (Fig. 8b). The Precambrian grains $(18 \%)$ are Neoproterozoic $(10 \%$; ca. 702-542 Ma), Paleoproterozoic (4 \%; ca. 2.1-1.6 Ga), Mesoproterozoic ( $3 \%$; ca. 1.4 and $1.6 \mathrm{Ga})$, and Neoarchean $(1 \%$; ca. $2.8 \mathrm{Ga})$. The youngest zircon population $(N=3$; ca. 319 $315 \mathrm{Ma}$ ) suggests a Bashkirian maximum depositional age, which is slightly older than the sedimentary age inferred from biostratigraphic constraints (middle Moscovian to Kasimovian; Lemos de Sousa and Wagner, 1983; Machado et al., 2012; Lopes et al., 2014).

\section{$5 \quad$ K-S test and MDS analysis: results}

We recognize that the representativeness of the detrital zircon grains of samples TM-1 and CB is not the most recommended for provenance analyses. However, we consider it important to present a preliminary comparison of detrital zircon populations of Visean marine siliciclastic rocks from the Toca da Moura and Cabrela volcano-sedimentary complexes because it seems to indicate variability in the sources. A table showing the K-S results (referred to as Fig. S1 throughout the text) can be found in the Supplement.

The K-S test performed on the Santa Susana sandstones shows that the detrital zircon populations of sample SS2 (lower member) and the SS upper member (i.e., it includes samples StSz2 and StSz4 from Dinis et al., 2018) are not significantly different (all ages: $P$ value $=0.169$; preCarboniferous ages: $P$ value $=0.879$ ) at the $5 \%$ confidence level (Fig. S1). A comparison of samples SS-1 and SS-2 reveals that they are significantly different $(P$ value $\leq 0.01)$. Unlike sample SS-2, the sample SS-1 detrital zircon population is significantly different $(P$ value $<0.01)$ from the SS upper population (Fig. S1), indicating that they are derived from distinct sources. Besides this, sample SS-1 is much closer to that of SS upper $(D$ value $=0.323)$ and more distant from sample SS-2 ( $D$ value $=0.465)$ with regards to the distance between cumulative probability curves (Fig. 8c).

In Fig. 9a, the MDS diagram produced with all ages shows sample SS-1 adjacent to Cabrela and Mértola siliciclastic rocks, while sample SS-2 is near the Mira, Santa Iria, and Represa detrital zircon populations. In the MDS diagram for pre-Carboniferous ages, sample SS-2 is juxtaposed with sample TM-3 and closest to the Mira, PhylliteQuartzite, and Tercenas formations (Fig. 9b), suggesting likely sources. Nevertheless, the probable contribution to SS2 samples of sediment derived from the oldest siliciclastic rocks from the PLZ, SPZ (i.e., Pulo do Lobo, Gafo, Ribeira de Limas, Atalaia, and Ronquillo formations; P-G-R-A$\mathrm{R})$, and OMZ sources cannot be excluded. Their detrital zircon populations are not significantly different enough (all ages: $P$ value $=0.003$ ) and not significantly different (preCarboniferous ages: $P$ value $=0.113-0.165$ ) at the $5 \%$ confidence level (Fig. S1). This similarity is also illustrated in the 
approximation between the SS-2, P-G-R-A-R, and OMZ populations in the MDS diagrams (Fig. 9).

$\mathrm{K}-\mathrm{S}$ test results for the comparison between samples SS2 and TM-3 indicate that they present not significantly different detrital zircon populations (all ages: $P$ value $=0.399$; pre-Carboniferous ages: $P$ value $=0.0 .411$ ) at the $5 \%$ confidence level (Fig. S1). Furthermore, their cumulative probability curves are much closer (Fig. 8d): $D$ values are 0.195 (all ages) and 0.203 (pre-Carboniferous ages) (Fig. S1). The close relationship of the two detrital zircon populations suggests that the Toca da Moura volcano-sedimentary complex directly supplied sediment to the Santa Susana Basin. However, the relationship described above does not extend to the entire Santa Susana Basin since sample SS-1 presents a greater degree of similarity with the Cabrela detrital zircon population as regards the proximity between cumulative probability curves (Fig. 8d) and MDS diagrams (Figs. 9a, b).

In addition, Cabrela siliciclastic rocks are significantly different at the 5\% confidence level from sample TM-3 ( $P$ values $<0.01)$ as regards the significant distance between them on the MDS diagram (Fig. 9a, b) and the significant distance between cumulative curves (Fig. 8d) with a $D$-value range of $0.712-0.731$ (Fig. S1). The difference found in the detrital zircon populations suggests that Cabrela and Toca da Moura siliciclastic rocks probably derived from different sources.

As a result of the $\mathrm{K}-\mathrm{S}$ test and MDS analyses, the Horta da Torre Formation is significantly different (Fig. S1) and is clearly separate (Fig. 9a, b) from all the other detrital zircon populations, ruling out the possibility of it being a source for the Toca da Moura and Cabrela volcano-sedimentary complexes or Santa Susana Formation siliciclastic rocks.

\section{Discussion}

\subsection{Chronostratigraphic framework}

The geochronological data presented in the present study provide the basis for the first chronostratigraphic record for the Carboniferous basins of the Santa Susana-São Cristovão region (SW Iberia). Dating of silicic volcanic rocks interbedded in the Toca da Moura and Cabrela volcano-sedimentary complexes constrain the interval of felsic magmatism to having occurred from ca. 335 to $331 \mathrm{Ma}$ (Visean; Fig. 6), complementing currently available biostratigraphic information for Toca da Moura and Cabrela siliciclastic rocks (Pereira et al., 2006; Lopes et al., 2014). U-Pb ages of the youngest detrital zircon grains from the siliciclastic rocks of the Toca da Moura and Cabrela volcano-sedimentary complexes (TM3 and $\mathrm{CB}$, respectively; Fig. 8a) provide maximum age constraints for these marine deposits. Their maximum depositional ages (ca. 351-348 Ma; Tournaisian) are slightly older than currently available biostratigraphic ages (Pereira et al., 2006; Lopes et al., 2014) but provide confirmation that both marine deposits are broadly contemporaneous.
Furthermore, the best estimate of the crystallization age of the Baleizão silicic intrusion provides a minimum age of $318 \pm 2 \mathrm{Ma}$ (Bashkirian; Fig. 7a) for the intra-Carboniferous unconformity. Zircon extracted from a pebble of granite found in a Santa Susana conglomerate yielded a crystallization age of ca. $303 \mathrm{Ma}$ for plutonic rock (Fig. 7b). This age estimate overlaps with the age range of ca. 305-303 Ma (i.e., the maximum depositional age range) obtained for the youngest population of detrital zircon grains from sandstone of the upper member (Dinis et al., 2018), complementing the currently available biostratigraphic information for the Santa Susana Formation (Machado et al., 2012; Lopes et al., 2014). Given the findings described above, a stratigraphic interval of approximately 13-17 Myr can be established for the intraCarboniferous unconformity, marking a change in depositional environment from marine to terrestrial in the OMZ. Basin-drainage and infill patterns most probably changed due to the rapid uplift of the Variscan-Appalachian orogenic belt, active during the waning stages of the Laurussia-Gondwana collision (i.e., late Carboniferous).

\subsection{Provenance and evolutionary model}

An initial important finding provides evidence that they are derived from different sources. The TM-3 population presents $64 \%$ Precambrian detrital zircon grains, while the CB population contains only $10 \%$ (Fig. 8a). Toca da Moura siliciclastic rocks have a greater affinity with the Phyllite-Quartzite, Tercenas, Santa Iria, and Represa formations (Fig. 9), indicating that detrital zircon populations were reproduced faithfully in SPZ and PLZ (Laurussiantype) sources. A contribution from the oldest siliciclastic sequences of PLZ (Pulo do Lobo, Atalaia, Gafo, and Ribeira de Limas formations) and OMZ (Gondwanan-type) sources cannot be ruled out for sample TM-3 (Fig. 9). The number of late to middle Devonian zircon grains in sample TM-3 (6\%) is smaller than that of the CB population (68\%) (Fig. 8a), suggesting that Cabrela siliciclastic rocks were most likely derived largely from a Devonian source consistent with a limited contribution from recycled ancient rocks (Pereira et al., 2012a). This indicates that the origin of the Visean Toca da Moura and Cabrela basins is most likely more closely linked to sources located in the SPZ and PLZ (Laurussian type) than in the OMZ (Gondwanan type). The evidence in the Visean Toca da Moura basin for the dissection of the inactive Devonian magmatic arc and the erosion of its plutonic roots, together with the recycling of the PLZ and SPZ Frasnian-Tournaisian siliciclastic sequences and OMZ basement rocks, differs from the evidence in the Cabrela basin. The significance of the involvement of distinct sources is that part of the region located on the boundary between the OMZ, PLZ, and SPZ (SW Iberia) was subjected to uplift while the remaining part underwent flexural subsidence. A similar tectonic setting has been put forward as an explanation for differences in stratigraphy found in the Pedroches synorogenic 

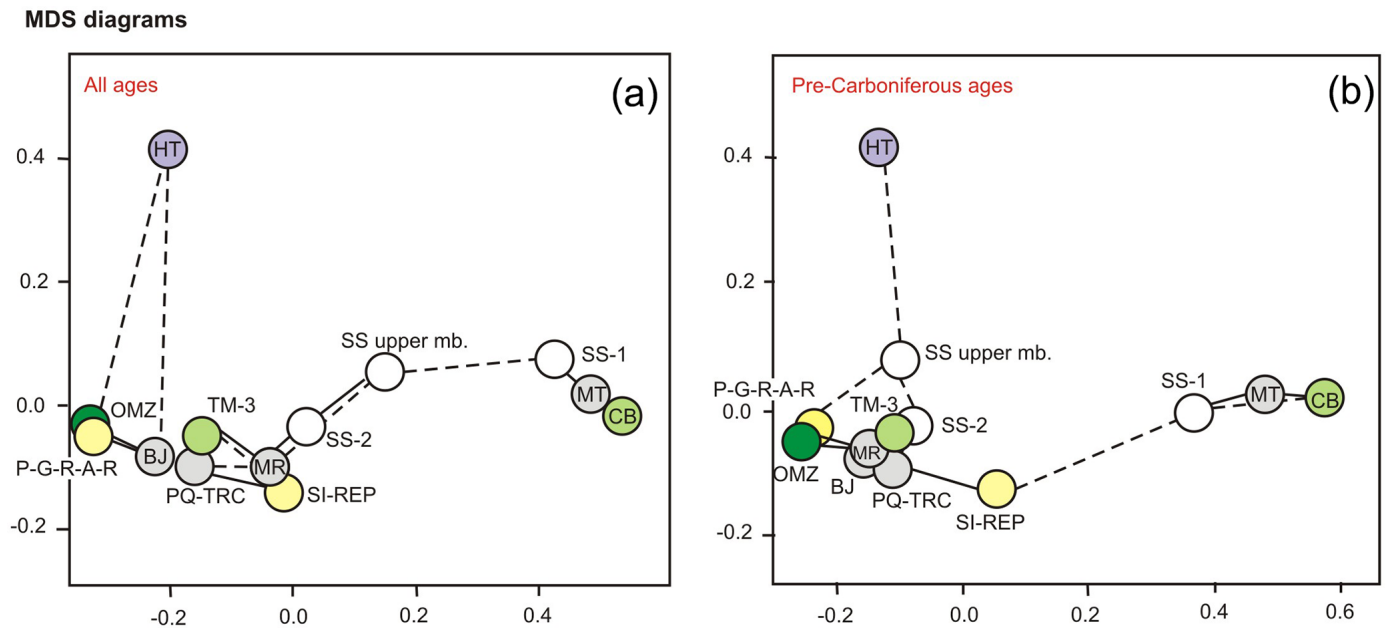

Figure 9. Multidimensional scaling diagrams (Vermeesch, 2018) applied to the U-Pb ages (90\%-110\% concordance) of detrital zircon grains from the Toca da Moura (TM-3) and Cabrela (CB) volcano-sedimentary complexes and the Santa Susana Formation (SS1, SS2, SS upper member) and different potential sources: OMZ (Linnemann et al., 2008; Pereira et al., 2008, 2012c), PLZ (Pereira et al., 2017a; Pérez Cácerez et al., 2017), and SPZ (Braid et al., 2011; Pereira et al., 2012a, 2014a; Rodrigues et al., 2014). Abbreviations: MT - Mértola Formation; MR - Mira Formation; BJ - Brejeira Formation; PQ-TRC - Phyllite-Quartzite and Tercenas formations; SI-REP - Santa Iria and Represa formations; P-G-R-A-R - Pulo do Lobo, Gafo, Ribeira de Lima, Atalaia and Ronquillo formations; HT - Horta da Torre Formation.

basin located along the OMZ-Central Iberian Zone boundary (Armendáriz et al., 2008, and references therein) (Fig. 1).

Over the past 4 decades, different models have emerged to explain the geodynamic evolution of SW Iberia with the subduction polarity being widely discussed (Quesada et al., 1994; Castro et al., 1996; Ribeiro et al., 2007; Pin et al., 2008; Simancas et al., 2009; Braid et al., 2011; PérezCáceres et al., 2015; Díez Fernández et al., 2016; Pereira et al., 2017a). Although in many paleogeographic reconstructions of the Devonian Iberia is flanked by the Rheic and Paleo-Tethys oceans (Stampfli et al., 2002, 2013; Cocks and Torsvik, 2006; Stampfli and Kozur, 2006; Torsvik et al., 2012; Arenas et al., 2014; von Raumer et al., 2016), solely the subduction of the Rheic Ocean is considered in the present geodynamic models for Iberia. This geodynamic model of a single ocean has been the trigger of numerous discussions about whether the active magmatic arc was located in Laurussia or Gondwana margins. Our challenging recent proposal considers that SW Iberia's geodynamic evolution could have been linked to the closure of these two oceanic basins (Pereira et al., 2020). The main assumption is that SPZ and PLZ (Laurussian side) and OMZ (Gondwana side) have experienced different and independent geodynamic evolutions before they were juxtaposed with the Variscan sinistral orogen-parallel motion (Pérez-Cáceres et al., 2016). As illustrated in Fig. 10a, the subduction of the Rheic Ocean floor beneath the Laurussian margin during the late Devonian (Pérez-Cáceres et al., 2015; Pereira et al., 2017a, and references therein) caused the onset of the Rheic magmatic arc in the Meguma terrane and related synorogenic basins. A slab rollback mechanism similar to the one that caused the opening of the Okinawa Trough behind the Ryukyu-type subduction in the Pacific Ocean (Yamaji, 2003; Boutelier and Cruden, 2013) could explain the lithosphere extension on the Laurussian side and the late Devonian siliciclastic sedimentation in SPZ and PLZ (Pereira et al., 2017a). The Laurussian active margin was progressively accreted to the Gondwana passive margin facing the Rheic Ocean during the late Devonian (Fig. 10a). A nappe stack was gradually emplaced in the Gondwana margin as a consequence of ongoing continental collision (Pérez-Cáceres et al., 2015; Díez Fernández and Arenas, 2015, and references therein; Díez Fernández et al., 2016) and orogenic gravitational collapse (Dias da Silva et al., 2020). Following the closure of the Rheic, Tournaisian magmatic episodes were associated with lithospheric extension in the Laurussian (Pyrite Belt volcano-sedimentary complex and Gil Márquez pluton) and Gondwanan (Beja Igneous Complex) margins. A mechanism of steepening and break-off of the Rheic Ocean slab beneath the Laurussian margin, as in the modern analog of Eastern Anatolian Alpine-Himalayan collisional mountain belt (Sengör et al., 2003; Keskin, 2007), was possibly the main reason for the early Carboniferous magma generation in the SPZ (Pin et al., 2008); simultaneously the Meguma terrane experienced rapid uplift and terrestrial sedimentation (Fig. 10b1). At the same time, on the Gondwanan side, the upwelling of the asthenosphere could have triggered the partial melting of crustal materials and lithosphere extension (Pereira et al., 2009, 2012b), creating the right conditions for the onset of gneiss domes in the OMZ (Dias da Silva et al., 2018). The emplacement of voluminous subductionrelated magmas (Santos et al., 1990; Castro et al., 1996; Je- 
sus et al., 2007; Pin et al., 2008; Lima et al., 2012; Pereira et al., 2007, 2015a; Moita et al., 2009, 2015), including some with boninitic (Castro et al., 1999) and adakitic (Lima et al., 2013) affinities, was coeval with flexural subsidence, marine sedimentation, and volcanism (Toca da Moura, Cabrela, and Los Pedroches basins) (Fig. 10b2). The early Carboniferous thermal anomaly recorded in the OMZ has been interpreted as resulting from the emplacement in the middle crust of a large volume of mantle plume-related magmas (Simancas et al., 2006). Other studies have suggested that voluminous early Carboniferous magmatism could have resulted from the subduction of an oceanic ridge, creating a slab window beneath the OMZ (Castro et al., 1996, 1999; Díaz-Azpiroz et al., 2006). This model uses the Chile ridge that plunges beneath the South American Plate in Patagonia (Breitsprecher and Thorkelson, 2009) as a modern analog. Our model assumes the subduction of a ridge of the PaleoTethys Ocean's lithosphere beneath the Gondwana margin (Fig. 10b2) instead of the Rheic Ocean's lithosphere as a hypothesis to be further explored since the magmatic activity has extended to the Serpukhovian and Bashkirian in the OMZ (Pavia pluton, Valencia del Ventoso plutonic complex, and Baleizão porphyry). Simultaneous with the putative subduction of the Paleo-Tethys Ocean ridge, other regions of the Variscan-Appalachian orogenic belt, mostly on the Laurussian side (Fig. 10b1), have experienced an oblique collision, rapid uplift, and terrestrial sedimentation (Pereira et al., 2020).

A second significant finding is that detrital zircon populations from the Santa Susana Formation (samples SS-1 and SS-2) also show significant differences (Figs. 8 and 9). Basal conglomerate (sample SS-2) presents a greater percentage of Precambrian grains (64\%) than uppermost sandstone (SS-1 sample; $28 \%$ ) and presents a great degree of affinity with the detrital zircon population of sample TM-3. Sample SS-2 presents a great degree of similarity with the detrital zircon populations of overlying SS upper-member sandstones (samples StSz-2 and StSz-4; Dinis et al., 2018) sampled as part of the same stratigraphic profile. SS-2 and SS upper age populations show a great degree of affinity (Fig. 9), suggesting that detrital zircon grains were mainly derived from the erosion of the Toca da Moura volcanosedimentary complex, the Santa Iria and Represa formations (PLZ), and the Mira Formation (SPZ). However, regarding the detrital zircon grains with pre-Carboniferous ages, additional contributions from other PLZ (Pulo do Lobo, Atalaia, Gafo, and Ribeira de Limas formations), SPZ (Brejeira, Phyllite-Quartzite, Tercenas, and Ronquillo formations), and OMZ sources cannot be ruled out (Fig. 9). The zircon age population of sample SS-1, which is distinct from the SS2 population, presents a great degree of affinity with the CB population, suggesting lateral changes in sources during the deposition of Santa Susana's uppermost sandstones. The great degree of affinity of the SS-1 with both the Cabrela volcano-sedimentary complex and Mértola Formation detri- tal zircon populations suggests a close association between the two and a common source. Cabrela and Mértola siliciclastic rocks may be regarded as the main source for sample SS-1 and an intermediate sediment repository as they are derived from the erosion of a Devonian source partially represented by the Cercal porphyries from the SPZ. As a result of rapid uplift, the progressive erosion of the Devonian magmatic arc (including its plutonic roots), and of PLZ, SPZ, and OMZ rocks, is evidenced in the Santa Susana Formation. The volumetrically significant contribution of Carboniferous sources to the Santa Susana Basin fill confirms derivation from the erosion of the following: (i) Pyrite Belt volcanic rocks and Phyllite-Quartzite, Tercenas, Mértola, Mira, and Brejeira siliciclastic rocks (SPZ); (ii) the Santa Iria and Represas formations (PLZ); (iii) Gil Marquez granitic rocks and other plutons of the Sierra del Norte Batholith (SPZ and PLZ); (iv) the Beja Igneous Complex, which includes the Baleizão porphyries (OMZ) and Évora and Pavia plutonic and high-grade metamorphic rocks (OMZ); and (v) the Cabrela and Toca da Moura volcano-sedimentary complexes (OMZ) and Mértola turbidites (SPZ). From the late Carboniferous to early Permian, large-scale strike-slip motions have juxtaposed OMZ with PLZ and SPZ (García-Navarro and Fernández, 2004; Pérez-Cáceres et al., 2016) and simultaneously with the rapid uplift of the Variscan orogenic belt (Fig. 10c). In Kasimovian-Gzhelian, sedimentation probably occurred through the opening of the pull-apart terrestrial basin (Santa Susana Basin) related to the movement of major strike-slip faults (i.e., Porto-Tomar fault zone; Pereira et al., 2010; Machado et al., 2012; Gutiérrez-Alonso et al., 2015) during the progressive uplift and buckling of the linear Variscan-Appalachian orogenic belt (i.e., OMZ, PLZ, and SPZ; Fig. 10c), related to a change in the regional stress field that produced the Greater Cantabrian Orocline (PastorGalán et al., 2015). U-Pb dating of magmatic zircon extracted from a pebble of granite (ca. 303 Ma; Fig. 7b) found in a conglomerate of the Santa Susana Formation lower member suggests provenance from the direct erosion of Permo-Carboniferous plutons (i.e., original primary source), such as Santa Eulália-Monforte granitic and gabbro-dioritic rocks (OMZ). This ca. 303-297 Ma calc-alkaline plutonic suite is coeval with the Nisa-Albuquerque and Los Pedroches batholiths, located on the OMZ-Central Iberian Zone boundary (Fig. 1), probably representing magmatism related to the eastward migration of the Paleo-Tethyan arc (PermoCarboniferous Pyrenees plutonic and volcanic rocks; Pereira et al., 2014, 2015b, 2017b). The Permo-Carboniferous OMZ plutons were emplaced at shallow crustal levels consistent with the low assimilation of country rocks and the sharp contacts, and, therefore, they may have experienced denudation shortly after crystallization without unrealistic uplift rates being required. 

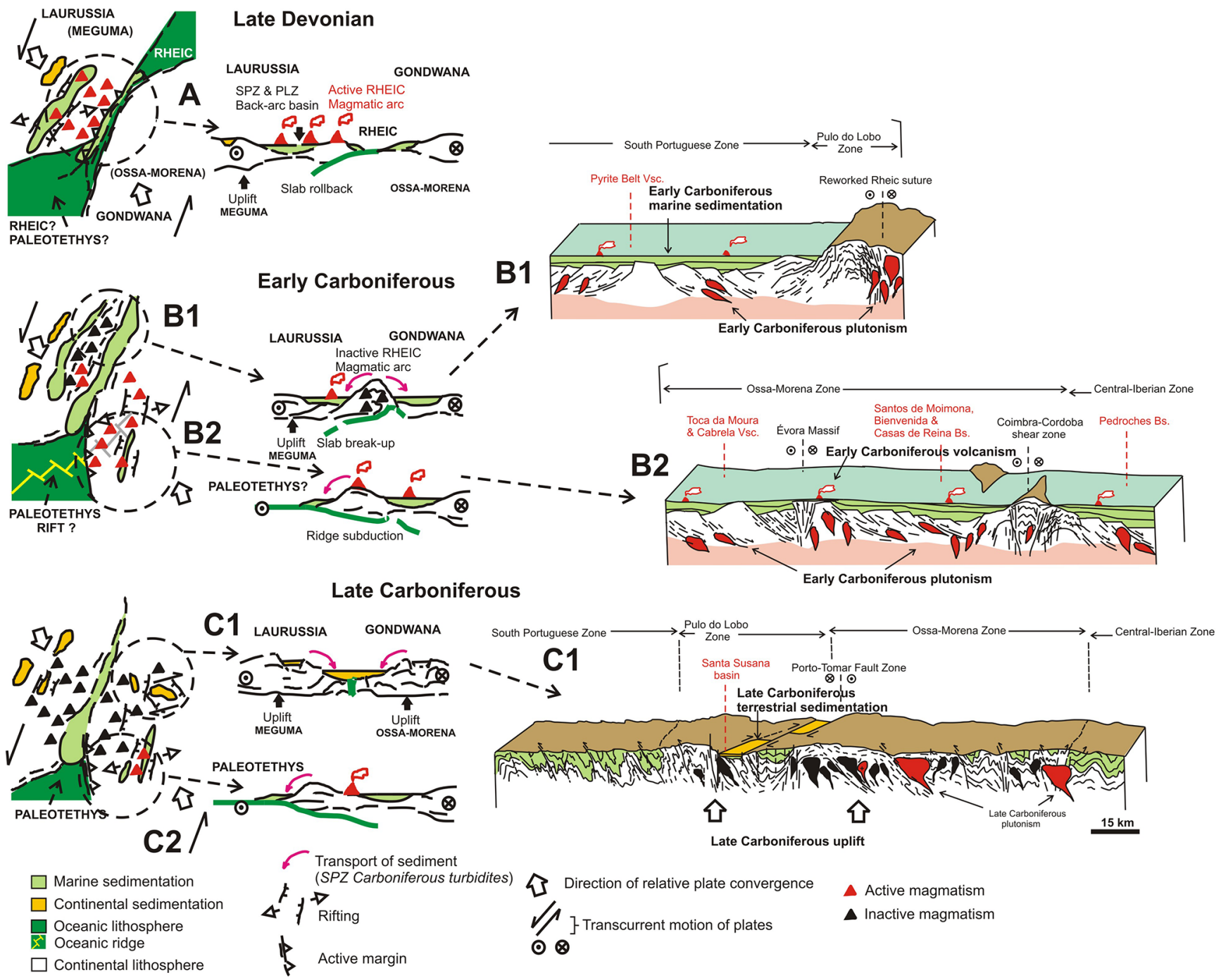

Figure 10. Sketches showing inferred tectonic evolution and sedimentation recorded in SW Iberian Carboniferous stratigraphy during the Laurussian-Gondwana oblique collision (modified from Pereira et al., 2012b, 2020): (a) late Devonian, (b1, b2) early Carboniferous, and (c1, c2) late Carboniferous.

\section{Conclusions}

The main conclusions of this study are the following.

1. Visean marine deposition in the Santa Susana-São Cristovão and Cabrela regions is constrained to the age range of ca. 335-331 Ma by the new U-Pb data for volcanic rocks intercalated within siliciclastic rocks of the Toca da Moura and Cabrela volcano-sedimentary complexes.

2. U-Pb dating of the Baleizão porphyry provides a minimum age of $318 \pm 2 \mathrm{Ma}$ (Bashkirian) for the overlying intra-Carboniferous unconformity.

3. Visean siliciclastic rocks from the Cabrela and Toca de Moura volcano-sedimentary complexes are derived from distinct sources, which probably include a Devonian continental magmatic arc, and are likely to be more closely associated with the Laurussian-type sources (SPZ and PLZ) than the Gondwanan-type sources (OMZ).

4. Terrestrial siliciclastic rocks from the Santa Susana Formation are probably the result of the recycling of distinct sources associated with the SPZ, PLZ, and OMZ.

5. The best estimate of crystallization of a granite pebble found in Santa Susana Formation conglomerate suggests a maximum depositional age of ca. $303 \mathrm{Ma}$ (Kasimovian-Gzhelian); together with the youngest $\mathrm{U}_{-}$ $\mathrm{Pb}$ ages $(<$ ca. $318 \mathrm{Ma})$ of detrital zircon grains, these findings provide evidence of the denudation of primary crystalline sources during the rapid post-accretion and 
collision uplift of the Variscan orogenic belt in SW Iberia (i.e., Gondwanan- and Laurussian-type sources).

6. The intra-Carboniferous unconformity that separates the Toca da Moura volcano complex and the Baleizão porphyry from the Santa Susana Formation indicates a notable time interval of approximately 13-17 Myr.

Data availability. The only data related to this publication regard the U-Pb results that are listed in Tables S1 and S2 of the Supplement.

Supplement. The supplement related to this article is available online at: https://doi.org/10.5194/se-11-1291-2020-supplement.

Author contributions. MFP designed the study and, together with CG, ÍDdS, and JBS, performed the geological mapping, sampling, and petrography. The geochronological study was conducted by CG, ÍDdS, MH, and AG and was supervised by MFP and UL. MFP, CG, íDdS, and JBS wrote the paper. Funding acquisition was achieved by MFP, CG, and ÍDdS. All authors have read and agreed to the published version of the paper.

Competing interests. The authors declare that they have no conflict of interest.

Special issue statement. This article is part of the special issue "The Iberian Massif in the frame of the European Variscan Belt". It is not associated with a conference.

Acknowledgements. This work is a contribution to projects CGL2016-76438-P and PGC2018-096534-B-I00 (Spain). Ícaro Dias da Silva acknowledges the financial support of SYNTHESIS3ACCESS (DE-TAF-5798), Fundação para a Ciência e a Tecnologia postdoctoral grant SFRH/BPD/99550/2014. This is IBERSIMS publication number 71 .

Financial support. This research has been supported by the Fundação para a Ciência e a Tecnologia (grant no. ICTUID/GEO/04683/2019), the Fundação para a Ciência e a Tecnologia (grant no. UID/GEO/50019/2019-IDL), and the Fundação para a Ciência e a Tecnologia (grant no. SFRH/BPD/99550/2014).

Review statement. This paper was edited by Emilio Clavijo and reviewed by Daniel Pastor-Galán and Antonio Castro.

\section{References}

Andrade, A. S.: Contribuition à l'Analyse de la Suture Hercynienne de Beja (Portugal), Perspectives Métallogéniques, unpublished PhD thesis, INPL, 137 pp., 1983.

Andrade, C. F.: Alguns elementos para o estudo dos depósitos de carvão do Moinho da Ordem, Comunicações dos Serviços Geológicos de Portugal, XVI, 3-28, 1927.

Arenas, R., Díez Fernández, R., Sánchez Martínez, S., Gerdes, A., Fernández-Suárez, J., and Albert, R.: Two-stage collision: exploring the birth of Pangea in the Variscan terranes, Gondwana Res., 25, 756-763, 2014.

Armendáriz, M., López-Guijarro, R., Quesada, C., Pin, C., and Bellido, F.: Genesis and evolution of a syn-orogenic basin in transpression: Insights from petrography, geochemistry and Sm-Nd systematics in the Variscan Pedroches basin (Mississippian, SW Iberia), Tectonophysics, 461, 395-413, 2008.

Azor, A., Rubatto, D., Simancas, J. F., González Lodeiro, F., Martínez Poyatos, D., Martín Parra, L. M., and Matas, J.: Rheic Ocean ophiolitic remnants in southern Iberia questioned by SHRIMP U-Pb zircon ages on the Beja-Acebuches amphibolites, Tectonics, 27, TC5006, https://doi.org/10.1029/2008TC002306, 2008.

Barbeau, D. L., Davis, J. T., Murray, K. E., Valencia, V., Gehrels, G. E., Zahid, K. M., and Gombosi, D. J.: Detrital-zircon geochronology of the metasedimentary rocks of north-western Graham Land, Antarct. Sci., 22, 65-78, 2009.

Boutelier, D. and Cruden, A.: Slab rollback rate and trench curvature controlled by arc deformation, Geology, 41, 911-914, 2013.

Bowring, S. A., Schoene, B., Crowley, J. L., Ramezani, J., and Condon, D. J.: High-precision U-Pb zircon geochronology and the stratigraphic record: Progress and promise, in: Geochronology: Emerging Opportunities, Paleontological Society Short Course, 21 October 2006, Philadelphia, PA, edited by: Olszewski, T., Paleontological Society Papers, 11, 23-43, 2006.

Braid, J. A., Murphy, J. B., Quesada, C., and Mortensen, J.: Tectonic escape of a crustal fragment during the closure of the Rheic Ocean: U-Pb detrital zircon data from the late Palaeozoic Pulo de Lobo and South Portuguese Zones, Southern Iberia, J. Geol. Soc. London, 168, 383-392, 2011.

Breitsprecher, K. and Thorkelson, D. J.: Neogene kinematic history of Nazca-Antarctic-Phoenix slab windows beneath Patagonia and the Antarctic Peninsula, Tectonophysics, 464, 10-20, 2009.

Caldeira, R., Ribeiro, M. L., and Moreira, M. E.: Geoquímica das sequências máficas e félsicas entre Alvito, Torrão e Alcáçovas (SW da ZOM), Comunicações Geológicas, 94, 5-28, 2007.

Castro, A., Fernández, C., de la Rosa, J. D., Moreno-Ventas, I., El Hmidi, H., El Biad, M., Bergamin, J. F., and Sánchez, N.: Triplejunction migration during Paleozoic Plate convergence: The Aracena metamorphic belt, Hercynian massif, Spain, Geol. Rundsch., 85, 108-185, 1996.

Castro, A., Fernández, C., El-Hmidi, H., El-Bia, M., Díaz Azpiroz, M., de la Rosa, J. D., and Stuart, F.: Age constraints to the relationships between magmatism, metamorphism and tectonism in the Aracena metamorphic belt, southern Spain, Int. J. Earth Sci., 88, 26-37, 1999.

Chichorro, M., Pereira, M. F., Díaz-Azpiroz, M., Williams, I. S., Fernández, C., Pin, Ch., and Silva, J. B.: Cambrian ensialic riftrelated magmatism in the Ossa-Morena Zone (Évora-Aracena 
metamorphic belt, SW Iberian Massif): Sm-Nd isotopes and SHRIMP zircon U-Th-Pb geochronology, Tectonophysics, 461, 91-113, 2008.

Cocks, L. R. M. and Torsvik, T. H.: European geography in a global context from the Vendian to the end of the Palaeozoic, in: European Lithosphere Dynamics, edited by: Gee, D. G. and Stephenson, R. A., Geological Society, London, Memoirs, 32, 83-95, 2006.

DeGraaff-Surpless, K., Mahoney, J. B., Wooden, J. L., and McWilliams, M. O.: Lithofacies control in detrital zircon provenance studies: insights from the Cretaceous Methow Basin, Southern Canadian Cordillera, Geol. Soc. Am. Bull., 115, 899915, 2003

Dias da Silva, Í., Pereira, M. F., Silva, J. B., and Gama, C.: Timespace distribution of silicic plutonism in a gneiss dome of the Iberian Variscan Belt: The Évora Massif (Ossa-Morena Zone, Portugal), Tectonophysics, 747-748, 298-317, 2018.

Dias da Silva, Í., González Clavijo, E., and Díez-Montes, A.: The collapse of the Variscan belt: a Variscan lateral extrusion thin-skinned structure in NW Iberia, Int. Geol. Rev., https://doi.org/10.1080/00206814.2020.1719544, online first, 2020.

Díaz Azpiroz, M., Fernandez, C., Castro, A., and El-Biad, M.: Tectonometamorphic evolution of the Aracena metamorphic belt (SW Spain) resulting from ridge-trench interaction during Variscan plate convergence, Tectonics, 25, TC1001, https://doi.org/10.1029/2004TC001742, 2006.

Dickinson, W. R. and Gehrels, G. E.: Use of U-Pb ages of detrital zircons to infer maximum depositional ages of strata: a test against a Colorado Plateau Mesozoic database, Earth Planet. Sc. Lett., 288, 115-125, 2009.

Díez Fernández, R. and Arenas, R.: The Late Devonian Variscan suture of the Iberian Massif: a correlation of high-pressure belts in NW and SW Iberia, Tectonophysics, 654, 96-100, 2015.

Díez Fernández, R., Arenas, R., Pereira, M.F., Sánchez Martínez, S., Albert, R., Martín Parra, L. M., Rubio Pascual, F. J., and Matas, J.: Tectonic evolution of Variscan Iberia: GondwanaLaurussia collision revisited, Earth-Sci. Rev., 162, 269-292, 2016.

Dinis, P. A., Fernandes, P., Jorge, R. C. G. S., Rodrigues, B., Chew, D. M., and Tassinari, C. G.: The transition from Pangea amalgamation to fragmentation: constraints from detrital zircon geochronology on West Iberia paleogeography and sediment sources, Sediment. Geol., 375, 172-187, 2018.

Domingos, L. C. G., Freire, J. L. S., Silva, F. G., Gonçalves, F., Pereira, E., and Ribeiro, A.: The Structure of the Intramontane Upper Carboniferous Basins in Portugal, in: The Carboniferous of Portugal, edited by: Lemos de Sousa, M. J. and Oliveira, J. T., Memorias, Nova Série 29, Serviços Geológicos de Portugal, Lisboa, 187-194, 1983.

Fedo, C. M., Sircombe, K. N., and Rainbird, R. H.: Detrital zircon analysis of the sedimentary record, Rev. Mineral. Geochem., 53, 277-303, https://doi.org/10.2113/0530277, 2003.

Ferreira, P., Caldeira, R., and Calvo, R.: Geoquímica das rochas ígneas aflorantes na região de S. Matias, Cuba (Alentejo), Comunicações Geológicas, 101, Especial I, 93-97, 2014.

Fonseca, P., Munhá, J., Pedro, J., Rosas, F., Moita, P., Araújo, A., and Leal, N.: Variscan ophiolites and high-pressure metamorphism in southern Iberia, Ofioliti, 24, 259-268, 1999.
Frei, D. and Gerdes, A.: Precise and accurate in-situ U-Pb dating of zircon with high sample throughput by automated LA-SF-ICPMS, Chem. Geol., 261, 261-227, 2009.

Gama, C., Pereira, M. F., Crowley, Q. G., Dias da Silva, Í., and Silva, J. B.: Detrital zircon provenance of Triassic sandstone of the Algarve Basin (SW Iberia): Evidence of Gondwanan- and Laurussian-type sources of sediment, Geol. Mag., 157, 1-19, https://doi.org/10.1017/S0016756820000370, 2020.

García-Navarro, E. and Fernández, C.: Final stages of the Variscan Orogeny at the southern Iberian massif: Lateral extrusion and rotation of continental blocks, Tectonics, 23, TC6001, https://doi.org/10.1029/2004TC001646, 2004.

Gehrels, G. E.: Detrital zircon U-Pb geochronology applied to tectonics, Annu. Rev. Earth Pl. Sc., 42, 127-149, 2014.

Gonçalves, F. and Carvalhosa, A.: Subsídios para o conhecimento geológico do Carbónico de Santa Susana, Vol. D’ Hommage au géologue G. Zbyszewski, Recherche de Civilisations, Paris, 109130, 1984.

Gutiérrez-Alonso, G., Collins, A. S., Fernández-Suárez, J., PastorGalán, D., González-Clavijo, E., Jourdan, F., Weil, A. B., and Johnston, S. T.: Dating of lithospheric buckling: ${ }^{40} \mathrm{Ar} /{ }^{39} \mathrm{Ar}$ ages of syn-orocline strike-slip shear zones in northwestern Iberia, Tectonophysics, 643, 44-54, 2015.

Guynn, J. and Gehrels, G. E.: Comparison of detrital zircon age distributions in the K-S test, University of Arizona, Arizona LaserChron Center, Tucson, 16 pp., 2010.

Jesus, A., Munhá, J., Mateus, A., Tassinari, C., and Nutman, A.: The Beja layered gabbroic sequence (Ossa-Morena Zone, Southern Portugal): geochronology and geodynamic implications, Geodin. Acta, 20, 139-157, 2007.

Jesus, A. P., Mateus, A., Munhá, J. M., Tassinari, C. G., Bento dos Santos, T. M., and Benoit, M.: Evidence for underplating in the genesis of the Variscan synorogenic Beja Layered Gabbroic Sequence (Portugal) and related mesocratic rocks, Tectonophysics, 683, 148-171, 2016.

Keskin, M.: Eastern Anatolia: A hotspot in a collision zone without a mantle plume, in: Plates, plumes, and planetary processes, edited by: Foulger, G. R. and Jurdy, D. M., Geol. S. Am. S., 430, 693-722, 2007.

Lemos de Sousa, M. J. and Wagner, R. H.: General description of the terrestrial Carboniferous basins in Portugal and history of investigations, in: The Carboniferous of Portugal, edited by: Lemos de Sousa, M. J. and Oliveira, J. T., Memórias dos Serviços Geológicos de Portugal, 29, 117-126, 1983.

Lima, S. M., Corfu, F., Neiva, A. M. R., and Ramos, M. F.: Dissecting complex magmatic processes: an in-depth $\mathrm{U}-\mathrm{Pb}$ study of the Pavia Pluton, Ossa-Morena Zone, Portugal, J. Petrol., 53, 1887 1911, 2012.

Lima, S. M., Neiva, A. M. R., and Ramos, J. M. F.: Adakiticlike magmatism in western Ossa-Morena Zone (Portugal): Geochemical and isotopic constraints of the Pavia pluton, Lithos, 160-161, 98-116, 2013.

Linnemann, U., Pereira, M. F., Jeffries, T., Drost, K., and Gerdes, A.: Cadomian orogeny and the opening of the Rheic Ocean: new insights in the diachrony of geo-tectonic processes constrained by LA-ICP-MS U-Pb zircon dating (Ossa-Morena and SaxoThuringian Zones, Iberian and Bohemian Massifs), Tectonophysics, 461, 21-43, 2008. 
Lopes, G., Pereira, Z., Fernandes, P., Wicander, R., Matos, J.X., Rosa, D., and Oliveira, J. T.: The significance of reworked palynomorphs (middle Cambrian to Tournaisian) in the Visean Toca daMoura Complex (South Portugal). Implications for the geodynamic evolution of Ossa Morena Zone, Rev. Palaeobot. Palyno., 200, 1-23, 2014.

Ludwig, K. R.: User's manual for Isoplot/Ex version 3.00, a geochronological toolkit for Microsoft Excel, Berkeley Geochronology Center Special Publications, 4, 72 pp, 2003.

Machado, G., Dias da Silva, I., and Almeida, P.: Palynology, stratigraphy and geometry of the Pennsylvanian continental Santa Susana Basin (SW Portugal), J. Iber. Geol., 38, 429-448, 2012.

Moita, P., Santos, J. F., and Pereira, M. F.: Layered granitoids: interaction between continental crust recycling processes and mantlederived magmatism. Examples from the Évora Massif (OssaMorena Zone, southwest Iberia, Portugal), Lithos, 111, 125-141, 2009.

Moita, P., Santos, J. F., Pereira, M. F., Costa, M. M., and Corfu, F.: The quartz-dioritic Hospitais intrusion (SW Iberian Massif) and its mafic microgranular enclaves - evidence for mineral clustering, Lithos, 224-225, 78-100, 2015.

Oliveira, J. T., Oliveira, V., and Piçarra, J.: Traços gerais da evolução tectono-estratigráfica da Zona de Ossa Morena, em Portugal, Cad. Lab. Xeol. Laxe, 16, 221-250, 1991.

Pastor-Galán, D., Ursem, B., Meere, P. A., and Langereis, C.: Extending the Cantabrian Orocline to two continents (from Gondwana to Laurussia). Paleomagnetism from South Ireland, Earth Planet. Sc. Lett., 432, 223-231, 2015.

Pereira, M. F., Chichorro, M., Linnemann, U., Eguiluz, L., and Silva, J. B.: Inherited arc signature in Ediacaran and Early Cambrian basins of the Ossa-Morena Zone (Iberian Massif, Portugal): Paleogeographic link with European and North African correlatives, Precambrian Res., 144, 297-315, 2006.

Pereira, M. F., Silva, J. B., Chichorro, M., Moita, P., Santos, J. F., Apraiz, A., and Ribeiro, C.: Crustal growth and deformational processes in the Northern Gondwana margin: constraints from the Évora Massif (Ossa-Morena Zone, SW Iberia, Portugal), in: The evolution of the Rheic Ocean: from Avalonian-Cadomian active margin to Alleghenian-Variscan Collision, edited by: Linnemann, U., Nance, R. D., Kraft, P., and Zulauf, G., Geol. S. Am. S., 423, 333-358, 2007.

Pereira, M. F., Chichorro, M., Williams, I. S., and Silva, J. B.: Zircon $\mathrm{U}-\mathrm{Pb}$ geochronology of paragneisses and biotite granites from the SW Iberia Massif. (Portugal): evidence for a paleogeographic link between the Ossa-Morena Ediacaran basins and the West African craton, in: The Boundaries of the West African Craton, edited by: Ennih, N. and Liégeois, J. P., Geological Society, London, Special Publications, 297, 385-408, 2008.

Pereira, M. F., Chichorro, M., Williams, I. S., Silva, J. B., Fernandez, C., Diaz-Azpiroz, M., Apraiz, A., and Castro, A.: Variscan intra-orogenic extensional tectonics in the Ossa-Morena Zone (Évora-Aracena-Lora del Rio metamorphic belt, SW Iberian Massif): SHRIMP zircon U-Th-Pb geochronology, in: Ancient Orogens and Modern Analogues, edited by: Murphy, J. B., Keppie, J. D., and Hynes, A. J., Geological Society, London, Special Publications, 327, 215-237, 2009.

Pereira, M. F., Silva, J. B., Drost, K., Chichorro, M., and Apraiz, A.: Relative timing of transcurrent displacements in northern Gondwana: New U-Pb laser ablation MS-ICP-MS zircon and mon- azite geochronology of gneisses and sheared granites from the Western Iberian Massif (Portugal), Gondwana Res., 17, 461-481, 2010.

Pereira, M. F., Chichorro, M., Johnston, S., Gutiérrez-Alonso, G., Silva, J., Linnemann, U., Hofmann, M., and Drost, K.: The missing Rheic ocean magmatic arcs: provenance analysis of Late Paleozoic sedimentary clastic rocks of SW Iberia, Gondwana Res., 22, 882-891, 2012a.

Pereira, M. F., Chichorro, M., Silva, J., Ordóñez-Casado, B., Lee, J., and Williams, I.: Early Carboniferous wrenching, exhumation of high-grade metamorphic rocks and basin instability in SW Iberia; constrains derived from structural geology and $\mathrm{U}-\mathrm{Pb}$ and ${ }^{40} \mathrm{Ar}-$ ${ }^{39}$ Ar geochronology, Tectonophysics, 558-559, 28-44, 2012b.

Pereira, M. F., Solá, A. R., Chichorro, M., Lopes, L., Gerdes, A., and Silva, J. B.: North-Gondwana assembly, break-up and paleogeography: $\mathrm{U}-\mathrm{Pb}$ isotope evidence from detrital and igneous zircons of Ediacaran and Cambrian rocks of SW Iberia, Gondwana Res., 22, 866-881, 2012c.

Pereira, M. F., Ribeiro, C., Vilallonga, F., Chichorro, M., Drost, K., Silva, J. B., Albardeiro, L., Hofmann, M., and Linnemann, U.: Variability over time in the sources of South Portuguese Zone turbidites: evidence of denudation of different crustal blocks during the assembly of Pangea, Int. J. Earth Sci., 103, 1453-1470, 2014a.

Pereira, M. F., Castro, A., Chichorro, M., Fernández, C., DiazAlvarado, J., Martí, J., and Rodriguez, C.: Chronological link between deep-seated processes in magma chambers and eruptions: Permo-Carboniferous magmatism in the core of Pangaea (Southern Pyrenees), Gondwana Res., 25, 290-308, 2014b.

Pereira, M. F., Chichorro, M., Moita, P., Santos, J. F., Solá, A. M. R., Williams, I. S., Silva, J. B., and Armstrong, R. A.: The multistage crystallization of zircon in calc-alkaline granitoids: $\mathrm{U}-\mathrm{Pb}$ age constraints on the timing of Variscan tectonic activity in SW Iberia, Int. J. Earth Sci., 104, 1167-1183, $2015 a$.

Pereira, M. F., Castro, A., and Fernández, C.: The inception of a Paleotethyan magmatic arc in Iberia, Geosci. Front., 6, 297-306, 2015b.

Pereira, M. F., Gutiérrez-Alonso, G., Murphy, J. B., Drost, K., Gama, C., and Silva, J. B.: Birth and demise of the Rheic Ocean magmatic arc(s): Combined $\mathrm{U}-\mathrm{Pb}$ and $\mathrm{Hf}$ isotope analyses in detrital zircon from SW Iberia siliciclastic strata, Lithos, 278-281, 383-399, 2017a.

Pereira, M. F., Gama, C., and Rodríguez, C.: Coeval interaction between magmas of contrasting composition (Late CarboniferousEarly Permian Santa Eulália-Monforte massif, Ossa-Morena Zone): field relationships and geochronological constraints, Geol., Acta, 15, 409-428, 2017b.

Pereira, M. F., Martínez Poyatos, D., Pérez-Cáceres, I., Gama, C., and Azor, A.: Comment on "Stratigraphy of the Northern Pulo do Lobo Domain, SW Iberia Variscides: A palynological contribution" by Zélia Pereira et al. (2018) - Geobios, 51, 491-506", Geobios, 55, 103-106, 2019.

Pereira, M. F., Gama, C., Dias da Silva, Í., Fuenlabrada, J. M., Silva, J. B., and Medina, J.: Isotope geochemistry evidence for Laurussian-type sources of South-Portuguese Zone Carboniferous turbidites (Variscan orogeny), in: Pannotia to Pangea: Neoproterozoic and Paleozoic orogenic cycles in the circum-North Atlantic region, edited by: Murphy, J. B., Geological Society, 
London, Special Publications, https://doi.org/10.1144/SP5032019-163, 2020.

Pérez-Cáceres, I., Martínez Poyatos, D., Simancas, J. F., and Azor, A.: The elusive nature of the Rheic Ocean suture in SW Iberia, Tectonics, 34, 2429-2450, 2015.

Pérez-Cáceres, I., Simancas, J. F., Martínez Poyatos, D., Azor, A., and González Lodeiro, F.: Oblique collision and deformation partitioning in the SW Iberian Variscides, Solid Earth, 7, 857-872, https://doi.org/10.5194/se-7-857-2016, 2016.

Pérez-Cáceres, I., Poyatos, D. M., Simancas, J. F., and Azor, A.: Testing the Avalonian affinity of the South Portuguese Zone and the Neoproterozoic evolution of SW Iberia through detrital zircon populations, Gondwana Res., 42, 177-192, 2017.

Pin, C., Fonseca, P. E., Paquette, J. L., Castro, P., and Matte, P.: The ca. 350 Ma Beja igneous complex: a record of transcurrent slab break-off in the southern Iberia Variscan Belt?, Tectonophysics, 461, 356-377, 2008.

Priem, H. N. A., Boelrijk, N. A. I. M., Hebeda, E. H., and Schermerhorn, L. J. G.: Isotopic ages of the Alcáçovas orthogneiss and the Beja porphyries, South Portugal, Comunicações Serviços Geológicos Portugal, 72, 3-7, 1986.

Quesada, C. and Oliveira, J. T.: The Geology of Iberia: A Geodynamic Approach, vol. 2: The Variscan Cycle, volume coordinator: Simas, F., Regional Geology Reviews, Springer, 1-542, 2019.

Quesada, C., Robardet, M., and Gabaldon, V.: Ossa-Morena Zone. Stratigraphy. Synorogenic phase (Upper DevonianCarboniferous-Lower Permian), in: Pre-Mesozoic Geology of Iberia, edited by: Dallmeyer, R. D. and Martínez García, E., Springer-Verlag, Berlin-Heidelberg, 273-279, 1990.

Quesada, C., Fonseca, P. E., Munha, J., Oliveira, J. T., and Ribeiro, A.: The Beja-Acebuches Ophiolite (Southern Iberia Variscan fold belt): geological characterization and significance, Boletin Geológico y Minero, 105, 3-49, 1994.

Ribeiro, A., Munhá, J., Dias, R., Mateus, A., Pereira, E., Ribeiro, L., Fonseca, P., Araújo, A., Oliveira, T., Romão, J., Chaminé, H., Coke, C., and Pedro, J.: Geodynamic evolution of the SW Europe Variscides, Tectonics, 26, TC6009, https://doi.org/10.1029/2006TC002058, 2007.

Rodrigues, B., Chew, D. M., Jorge, R. C. G. S., Fernandes, P., VeigaPires, C., and Oliveira, J. T.: Detrital zircon geochronology of the Carboniferous Baixo Alentejo Flysch Group (South Portugal); constraints on the provenance and geodynamic evolution of the South Portuguese Zone, J. Geol. Soc. London, 172, 294-308, https://doi.org/10.1144/jgs2013-084, 2014.

Rosas, F. M., Marques, F. O., Ballevre, M., and Tassinari, C.: Geodynamic evolution of the SW Variscides: orogenic collapse shown by new tectonometamorphic and isotopic data from western Ossa-Morena Zone, SW Iberia, Tectonics, 27, TC0080, https://doi.org/10.1029/2008TC002333, 2008.

Santos, J., Mata, J., Gonçalves, F., and Munhá, J.: Contribuição para o conhecimento Geológico-Petrológico da Região de Santa Susana: O Complexo Vulcano-sedimentar da Toca da Moura, Comunicações dos Serviços Geológicos de Portugal, 73, 29-48, 1987.

Santos, J. F., Andrade, A. S., and Munhá, J.: Magmatismo orogénico Varisco no limite meridional da Zona de OssaMorena, Comunicações dos Serviços Geológicos de Portugal, 76, 91-124, 1990.
Sengör, A. M. C., Özeren, S., Zor, E., and Genç, T.: East Anatolian high plateau as a mantle-supported, north-south shortened domal structure, Geophys. Res. Lett., 30, 8045, https://doi.org/10.1029/2003GL017858, 2003.

Simancas, J. F., Tahiri, A., Azor, A., González Lodeiro, F., Martínez Poyatos, D., and El Hadi, H.: The tectonic frame of the VariscanAlleghanian orogen in southern Europe and northern Africa, Tectonophysics, 398, 181-198, 2005.

Simancas, J. F., Carbonell, R., González Lodeiro, F., Pérez Estaún, A., Juhlin, C., Ayarza, P., Kashubin, A., Azor, A., Martínez Poyatos, D., Sáez, R., Almodóvar, G. R., Pascual, E., Flecha, I., and Martí, D.: Transpressional collision tectonics and mantle plume dynamics: the Variscides of southwestern Iberia, Geological Society of London Memoirs, 32, 345-354, 2006.

Simancas, J. F., Azor, A., Martínez Poyatos, D. J., Tahiri, A., El Hadi, H., González-Lodeiro,F., Pérez-Estaún, A., and Carbonell, R.: Tectonic relationships of Southwest Iberia with the allochthons of Northwest Iberia and the Moroccan Variscides, C. R. Geosci., 341, 103-113, 2009.

Spencer, C. J., Kirkland, C. L., and Taylor, R. J. M.: Strategies towards statistically robust interpretations of in situ $\mathrm{U}-\mathrm{Pb}$ zircon geochronology, Geosci. Front., 7, 581-589, 2015.

Stampfli, G. M. and Kozur, H. W.: Europe from the Variscan to the Alpine Cycles, in: European Lithosphere Dynamics, edited by: Gee, D. G. and Stephenson, R. A., Geological Society of London, Memoirs, 32, 57-82, 2006.

Stampfli, G. M., von Raumer, J., and Borel, G. D.: The Palaeozoic evolution of pre-Variscan terranes: from peri-Gondwana to the Variscan collision, in: Variscan Appalachian Dynamics: The Building of the Upper Paleozoic Basement, edited by: MartinezCatalan, J. R., Hatcher, R. D., Arenas, R., and Diaz Garcia, F., Geol. S. Am. S., 364, 263-280, 2002.

Stampfli, G. M., Hochard, C., Vérard, C., Wilhem, C., and von Raumer, J.: The formation of Pangea, Tectonophysics, 593, 119, 2013.

Teixeira, C.: Sobre a flora fóssil do Carbónico alentejano, Boletim do Museu e Laboratório Mineralógico e Geológico da Universidade de Lisboa, $3^{\mathrm{a}}$ série 7/8, 83-100, 1938-1940.

Teixeira, C.: Sur quelques insectes fossiles du Carbonifere de l'Alentejo, Anais Faculdade de Ciências, Porto, XXVI, 2, 117 120, 1941.

Teixeira, C.: O Antracolítico continental português O Antracolítico continental português. (Estratigrafia e Tectónica), Boletim da Sociedade Geológica de Portugal, Pôrto, 5, Fasc. 1-2, 1-139, 1944

Torsvik, T. H., Van der Voo, R., Preeden, U., Mac Niocaill, C., Steinberger, B., Doubrovine, P. V., van Hinsbergen, D. J. J., Domeier, M., Gaina, C., Tohve, E., Meert, J. G., McCausland, P. J. A., and Cocks, R. M.: Phanerozoic polar wander, paleogeography and dynamics, Earth-Sci. Rev., 114, 325-368, 2012.

Vermeesch, P.: How many grains are needed for a provenance study?, Earth Planet. Sc. Lett., 224, 441-451, 2004.

Vermeesch, P.: Multi-sample comparison of detrital age distributions, Chem. Geol., 341, 140-146, 2013.

Vermeesch, P.: IsoplotR: A free and open toolbox for geochronology, Geosci. Front., 9, 1479-1493, 2018.

von Raumer, J. F., Nesbor, H.-D., and Stampfli, G. M.: The northsubducting Rheic Ocean during the Devonian: consequences for the Rhenohercynian ore sites, Int. J. Earth Sci., 106, 2279-2296, https://doi.org/10.1007/s00531-016-1425-x, 2016. 
Wagner, R. H. and Lemos de Sousa, M. J.: The Carboniferous megafloras of Portugal-a revision of identifications and discussion of stratigraphic ages, in: The Carboniferous of Portugal, edited by: Sousa, M. J. L. and Oliveira, J. T., Memórias dos Serviços Geológicos de Portugal, Lisboa, 127-152, 1983.

Wissink, G. K., Wilkinson, B. H., and Hoke, G. D: Pairwise sample comparisons and multidimensional scaling of detrital zircon ages with examples from the North American platform, basin, and passive margin settings, Lithosphere, 10, 478-491, 2018.
Yamaji, A.: Slab rollback suggested by latest Miocene to Pliocene forearc stress and migration of volcanic front in southern Kyushu, northern Ryukyu Arc, Tectonophysics, 364, 9-24, 2003. 